\title{
OVERCOMING THE BARBARIAN. DEPICTIONS OF ROME'S ENEMIES IN TRAJANIC MONUMENTAL ART
}

By

\author{
J.C.N. COULSTON*
}

Discourse on Roman imperialism has traditionally centred on a perspective firmly reflecting ancient élite sources, with the actions and motives of the Roman state being of paramount concern. Opponents to Roman ordering of the world, the 'neighbours' outside the empire, have generally taken second place in a hierarchy of scholarly priorities. This has been the case for a number of readily comprehensible reasons, not least of which is the symbiosis between Roman imperial studies and the past outlooks of researchers working against a contemporary imperial backdrop or in a post-colonial world still dominated by imperial 'consequences'. The priority of a Roman cultural gradient over both 'native' societies within the boundaries of the empire, and neighbouring groupings without, is striking and continues to be prominent in discourses on 'Romanisation'. Reference to the 'native background' in Roman provincial discussions before the 1990s, automatically both reinforced and perpetuated traditionalist models of culture change.

Certainly there was 'Romanisation' whereby elements of Roman Mediterranean culture did have an impact on a great range of core and hinterland societies. Urban institutions and elite practices, religious mechanisms, language and the 'contact culture' of military systems undeniably spread - the 'benefits of civilisation' in the traditional view. However, it has less often been seriously asked how cultural contacts and the existence of empire reflected back on the dominant culture, how the barbarians changed Rome whilst they were being acculturated. Moreover, a conservative over-dependence on the ancient elite literary record to provide both framework and outlook for the treatment of other, mainly

\footnotetext{
* The writer is very grateful to Lukas de Blois for his invitations to take part in the Impact of Empire conference in Rome and to contribute to the present volume. A particular debt is owed to the following friends and colleagues for discussions relating to various aspects of the subject in hand: Mike Bishop, Hazel Dodge, Andrew Gammon, Tom Harrison, Fraser Hunter, Simon James, Adriano La Regina, Greg Woolf and various discussants at the conference. Hazel Dodge kindly read the manuscript and made many helpful improvements on it.
} 
archaeologically derived, data has often relegated 'natives' to a subordinate proto-historic or non-historic position. ${ }^{1}$

There is a clear similarity here with modern discourses concerning more recent imperialisms. The idea that the rulers gave and the ruled took without cultural return has led to similar one-way perceptions. This is one of the thrusts of Edward Said's Culture and Imperialism which attempts to establish greater appreciation of exchange:

"The asymmetry is striking. In one instance we assume that the better part of history in colonial territories was a function of the imperial intervention; in the other, there is an equally obstinate assumption that colonial undertakings were marginal and perhaps even eccentric to the central activities of the great metropolitan cultures. Thus, the tendency in anthropology, history and cultural studies in Europe and the United States is to treat the whole of world history as viewable by a kind of Western super-subject, whose historicizing and disciplinary rigour either takes away, or, in the post-colonial period, restores history to people and cultures 'without' history. Few full-scale critical studies have focussed on the relationship between modern Western imperialism and its culture, the occlusion of that deeply symbiotic relationship being a result of the relationship itself."

A special symbiosis has been created by modern imperialism being fuelled by modern perceptions of Roman imperial power, sometimes specifically because the same geographical regions were involved (e.g. Italian aspirations in North Africa), sometimes because it was thought desirable to adopt supposed Roman imperial iconographic symbols (e.g. the use of the imperial eagle as a logo for successive Napoleonic régimes, or the fasces by 20th

\footnotetext{
${ }^{1}$ For introductions to the growing literature of this debate see M. Wood \& F. Queiroga (ed.), Current Research on the Romanization of the Western Provinces, BAR International Series 575 (Oxford 1992); J. Webster \& N. Cooper (ed.), Roman Imperialism: Post-Colonial Perspectives (Leicester 1996); G. Woolf, Becoming Roman. The Origins of Provincial Civilization in Gaul (Cambridge 1998); E. Fentress (ed.), Romanization and the City: Creation, Transformations and Failures, Journal of Roman Archaeology Supplementary Series 38 (Portsmouth 2000).

${ }^{2}$ E. Said, Culture and Imperialism (London 1993), 40.
} 
century fascist régimes). ${ }^{3}$ However, amongst many other major differences between Roman and modern imperialisms was the lack of any decisive technological gap between the Roman army and its adversaries on the battlefield. There was no Roman 'Military Revolution' in weaponry of a 16th to 19th century European kind, ${ }^{4}$ no need for the equivalent of Ellis's Social History of the Machine Gun ${ }^{5}$ to explore technological advantages over Rome's barbarian neighbours. Indeed, Roman military equipment was not only at the same 'tec-level' as the matériel of other peoples, but it was often made up of borrowings from other peoples, the 'Roman' element being largely the combination of arms and armour usages. ${ }^{6}$ Such a lack of Roman imperial technological superiority alone potentially made for profound differences between ancient and modern perceptions of the 'barbarian' or 'native' or 'other'. Nevertheless, there is great potential for cross-fertilisation between Roman studies and recent research on other imperialisms. ${ }^{7}$ For

\footnotetext{
${ }^{3}$ The eagle was employed to link military activities with Jupiter Capitolinus, the patron god of the Roman state, as with legionary aquilae, and the eagle-wings with fulmina blazons on shields carried by 1 st to 2 nd century $\mathrm{AD}$ citizen troops. The eagle was not generally employed separately as a state 'logo' in the manner of Habsburg imperial, German fascist, Mexican or U.S.A. eagles. The fasces represented individual magistrates and the emperor, and were depicted on the funerary monuments of such officials, but not to represent the state per se (see T. Schäfer, Imperii Insignia: sella curulis und fasces. Zur Repräsentation römischer Magistrate (Mainz 1989)).

${ }^{4}$ See G. Parker, The Military Revolution. Military Innovation and the Rise of the West, 1500-1800 (Cambridge 1988), chapter 4 . The confidence imparted by technologically superior weaponry could become arrogant over-confidence, and consequent defeats of colonial armies by 'natives' were commensurately more shocking, as in the Retreat from Kabul (1842), Little Big Horn (1876), Isandlwana (1879), Adowa (1896) etc. See G. Fincham, 'Writing colonial conflict, acknowledging colonial weakness', in G. Fincham, G. Harrison, R. Holland \& L. Revell (eds.), TRAC 2000. Proceedings of the Tenth Theoretical Roman Archaeology Conference (Oxford 2001), 25-34.

${ }^{5}$ J. Ellis, The Social History of the Machine Gun (London 1993), 79-109.

${ }^{6}$ Indeed Roman metallurgical technology was sometimes inferior to the capabilities of adversaries. The one obvious area of Roman superiority over all adversaries during the principate was artillery developments. See M.C. Bishop \& J.C.N. Coulston, Roman Military Equipment from the Punic Wars to the Fall of Rome (London 1993), 81; 194-195; 202-205.

${ }^{7}$ For multi-period studies see P.D.A. Garnsey \& C.R. Whittaker (eds.), Imperialism in the Ancient World (Cambridge 1978); J.A. Tainter, The Collapse of Complex Societies (Cambridge 1988); S.E. Alcock, T.N. D'Altroy, K.D. Morrison \& C.M. Sinopoli (eds.), Empires. Perspectives from Archaeology and History (Cambridge 2001). For discussions of the interractions between Roman and British imperialisms see P. Freeman, 'British imperialism and the Roman empire', in Webster \& Cooper 1996, op.cit. (n.1), 19-34; R. Hingley, 'The 'legacy' of Rome: the rise, decline, and fall of the theory of Romanization', in Webster \& Cooper 1996, op.cit. (n.1), 35-48; R. Hingley, Roman Officers and English Gentlemen: the Imperial Origins of Roman Archaeology (New York 2000). It has long been the practice to combine multi-period studies of military history within the same volume, e.g. J. Keegan, The Face of Battle (London 1978); J. Hackett, Warfare in the Ancient World
} 
instance, Kennedy's clear demonstration that an empire is in 'decline' once it starts to devote significant resources to defence rather than to expansion, has clear implications for the study of Roman frontier defences, especially if the principate of Trajan is regarded as the high-water mark of Roman military expansion and, indeed, over-extension. ${ }^{8}$

What follows is an examination of metropolitan Roman attitudes towards the 'barbarian' as expressed through the sculptures on Trajanic display monuments. The latter were created at the apogee of imperial strength in a triumphalist and confident style. Moreover, they are not merely singled out by accidents of survival and preservation, but they represent a combination of both traditional imperial rhetoric and the injection of hitherto unprecedented levels of verisimilitude into presentation of the barbarian enemy. The latter had been contacted in peace and war in the Danubian region for over a century. In one way or another, as ambassadors, exiles, prisoners of war, or as slaves, they had become familiar to Rome's élites and to her urban masses. Yet, under Trajan, these barbarians leapt for the first time into sharp focus in terms of dress, hairstyle and military equipment. Modern commentators may therefore attempt ethnographic identifications, but what makes this exercise so much more interesting and informative is the concern first with Roman ethnographic perceptions, and only second with the actualities of Danubian cultural formations. Moreover, this enquiry can be enhanced and informed by comparisons with the methods by which other imperial polities perceived and presented their own enemies in display art.

(London 1989); E. Carlton, War and Ideology (London 1990); P. Griffiths, Forward Into Battle. Fighting Tactics from Waterloo to the Near Future (Swindon 1990); A.B. Lloyd (ed.), Battle in Antiquity (London 1996); J. Carman (ed.), Material Harm. Archaeological Studies of War and Violence (Glasgow 1997); J. Carmen \& A. Harding (eds.), Ancient Warfare. Archaeological Perspectives (Stroud 1999); P. Bentley Kern, Ancient Siege Warfare (London 1999); V.D. Hanson, Why the West Has Won. Nine Landmark Battles in the Brutal History of Western Victory (London 2001); P.M.W. Freeman \& A. Pollard (eds.), Fields of Conflict. Progress and Prospect in Battlefield Archaeology, British Archaeological Reports International Series 958 (Oxford 2001).

${ }^{8} \mathrm{P}$. Kennedy, The Rise and Fall of the Great Powers. Economic Change and Military Conflict from 1500 to 2000 (London 1988), xvii; 298; 408. Cf. E.N. Luttwak, The Grand Strategy of the Roman Empire (Baltimore 1976), chapter 2. For Roman expansion and military exploration see C. Nicolet, Space, Geography and Politics in the Early Roman Empire (Ann Arbor 1991), 85-94. 


\section{Ancient 'barbarian' iconography}

In the field of Roman state iconography no period is better represented than the 2nd century $\mathrm{AD}{ }^{9}$ The sculptures of largely intact monuments such as Trajan's Column, ${ }^{10}$ the Great Trajanic Frieze, ${ }^{11}$ and the Column of Marcus Aurelius $^{12}$ provide literally thousands of representations of barbarians 'interacting' with the Roman emperors and their forces. Scenes of Roman victory and barbarian defeat, followed by submission and captivity commonly lauded the achievements of emperor and army in war. These have the character of having been executed at the centre of the empire, the core rather than the periphery, by sculptors with little or no direct experience of frontier 'reality'. Thus they may more closely represent elite imperialist perceptions at 'home' of distant enemies - the 'metropolitan' view in Said's terms. Moreover, there are contemporaneous works on the frontiers, such as the Tropaeum Traiani (Adamclissi, Romania) ${ }^{13}$ and private gravestone art, ${ }^{14}$

\footnotetext{
${ }^{9}$ In general see P.G. Hamberg, Studies in Roman Imperial Art with Special Reference to the State Reliefs of the 2nd Century (København 1945); D.E. Strong, Roman Imperial Sculpture (London 1961); D.E. Strong, Roman Art (London 1980), 128-132; 141-159; N. Hannestad, Roman Art and Imperial Policy (Aarhus 1986); D.E.E. Kleiner, Roman Sculpture (New Haven 1992), 183-194; $212-$ 235; G.M. Koeppel, 'Die historischen Reliefs der römischen Kaiserzeit, III, stadtrömische Denkmäler unbekannter Bauzugehörigkeit aus trajanischer Zeit', Bonner Jahrbücher 185 (1985), 143-213; G.M. Koeppel, 'Die historischen Reliefs der römischen Kaiserzeit, IV, stadtrömische Denkmäler unbekannter Bauzugehörigkeit aus hadrianischer bis konstantinischer Zeit', Bonner Jahrbücher 186 (1986), 1-90; Bishop \& Coulston 1993, op.cit. (n.6), 19-24.

${ }^{10}$ Fully reproduced in W. Froehner, La Colonne Trajane (Paris 1872-1874); C. Cichorius, Die Reliefs der Traianssäule (Berlin 1896-1900); K. Lehmann-Hartleben, Die Trajanssäule. Ein römisches Kunstwerk zu Beginn der Spätantike (Berlin 1926); F.B. Florescu, Die Trajanssäule (Bucaresti \& Bonn 1969); F. Lepper \& S. Frere, Trajan's Column (Gloucester 1988); S. Settis (ed.), La Colonna Traiana (Torino 1988); G.M. Koeppel, 'Die historischen Reliefs der römischen Kaiserzeit, VIII. Der Fries der Trajanssäule in Rom, Teil 1: Der Erste Dakische Krieg, Szenen ILXXVIII', Bonner Jahrbücher 191 (1991), 135-198; G.M. Koeppel, 'Die historischen Reliefs der römischen Kaiserzeit, IX. Der Fries der Trajanssäule in Rom, Teil 2: Der Zweite Dakische Krieg, Szenen LXXIX-CLV', Bonner Jahrbücher 192 (1992), 61-122; F. Coarelli, The Column of Trajan (Roma 2000). Cichorius is the best of these, Lepper and Frere the worst. Settis is in colour photography carried out before cleaning in the 1990s. See J.C.N. Coulston, 'Three new books on Trajan's Column', Journal of Roman Archaeology 3 (1990), 290-309. The Trajan's Column scene numbering system employed throughout the present study is that defined by Cichorius 1896-1900.

11 A.M. Leander Touati, The Great Trajanic Frieze. The Study of a Monument and of the Mechanisms of Message Transmission in Roman Art (Stockholm 1987).

${ }^{12}$ Fully reproduced in E. Petersen, A. von Domaszewski \& G. Calderini, Die Marcus-Säule auf Piazza Colonna in Rom (Monaco 1896); C. Caprino, La Colonna di Marco Aurelio (Roma 1955). The Marcus Column scene numbering system employed throughout the present study is that defined by Petersen et al. 1896.

${ }^{13}$ F.B. Florescu, Die Siegesdenkmal von Adamklissi: Tropaeum Traiani (Bucaresti 1965, 3rd ed.).
} 
often executed by soldiers drawing upon their own direct experience of nonRoman cultures, which may be used as a 'control' for metropolitan iconography. In Rome this was art for a public audience with content presumably, in some sense (although the mechanisms of commission and supervision are completely unknown), approved of by the régime and the elite of Roman society. ${ }^{15}$ The latter's outlook may of course be revealed by comparative studies of contemporary elite literature, such as Tacitus' Agricola and Germania, and the writings of Plinius Minor. ${ }^{16}$

Much which characterises the extraordinarily well preserved Trajan's Column was innovative and unprecedented, but of course triumphalist art was not invented in the early 2 nd century $\mathrm{AD}$. Various régimes back into the Bronze Age chose to commemorate and advertise military achievements, dedicating careful thought to the problems of depiction. The features which act as a unifying element for such works, including those of the 2nd century $\mathrm{AD}$, are: the common range of subject matter (marches, reviews, battles, sieges, submissions etc.); the necessity for intelligible conventions and clear depiction, thus the development of iconographic conventions and ethnocultural stereotypes; and the usual context of execution on a vertical wall. The last point is crucial, whether it involved a temple pylon, the walls of a palace, a tomb, or a dedicated monument such as a triumphal arch or column. The central problem was the translation of key actions such as battles and

${ }^{14}$ Collected in A. Hofmann, Römische Militärgrabsteine der Donauländer (Wien 1905); E. Espérandieu, Recueil général des bas-reliefs, statues et bustes de la Gaule romaine (Paris 19071966); E. Espérandieu, Recueil général des bas-reliefs, statues et bustes de la Germanie romaine (Paris 1931); A. Schober, Die römische Grabsteine von Noricum und Pannonien (Wien 1923); H. $\mathrm{Ubl}$, Waffen und Uniform des römischen Heeres der Prinzipatsepoche nach den Grabreliefs Noricums und Pannoniens (Wien 1969, Unpublished Ph.D. thesis); E. Pfühl \& H. Mobius, Die ostgriechischen Grabreliefs (Mainz 1977); N. Benseddik, Les troupes auxiliaires de l'armée romaine en Mauretanie Césarienne sous le Haut-Empire (Algiers 1979); M. Schleiermacher, Römische Reitergrabsteine. Die kaiserzeitlichen Reliefs der triumphierender Reiters (Bonn 1984); C. Franzoni, Habitus atque habitudo militis. Monumenti funerari di militari nella Cisalpina romana (Roma 1987); R.Tufi, Militari romani sul Reno (Roma 1988); plus volumes in the Corpus Signorum Imperii Romani for Britain, Germany, Austria, Poland and Hungary.

${ }^{15}$ For Trajan's principate see R. Scheiper, Bildpropaganda der römischen Kaiser unter besonderer Berücksichtigung der Traianssäule in Rom und korrespondierender Münzen (Bonn 1982).

${ }^{16}$ Cf. Livius 21.4.5-10; Velleius Paterculus 2.104.3-4; Tacitus, Agricola 20; 22; 33-38; Germania 18-22; Historiae 2.5; Josephus, Bellum Iudaicum 7.142-147; Plinius Minor, Panegyricus 13; 15; 19 ; Epistulae 8.4 (fitting subjects for a Dacian war history); Plutarch, Cato 1.6-7; Fronto, Ad Lucium Verum imp. 9-15; Dio Cassius 68.8; 68.8.14; 68.8.23; 69.9; SHA, Hadrianus 10.2-11.1. 
sieges which took place on an essentially flat or undulating plain with breadth and depth, onto a vertical, two-dimensional wall.

Common conventions included the employment of a 'stacked' or 'bird's-eye view' perspective over scenery and human figures arranged in lines, 'flocks' or confused masses. ${ }^{17}$ Because actions had to be visually intelligible, it was often necessary for human figures to be comparatively larger than life, dominating scenery, such as trees, walls and siege machines. A king or emperor was often rendered in even larger scale to denote status and to clarify his actions. Commonly the forces of said ruler were represented in ordered bodies or lines, whilst those of the 'barbarian' were disordered and confused. Thus the viewer was invited to infer irregularity, military inferiority and indiscipline for the adversary, leading to inevitable defeat. The careful depiction of specific cultural features such as clothing, weaponry and hairstyle also became a topos of enemy identification.

A number of pre-Roman examples may serve to illustrate these features and also to place the 2nd century AD material in a developmental context. In Pharaonic Egyptian art the king was depicted on large scale wall sculptures battling a series of cardinal enemies who were clearly identified not just in the inscriptions but visually by their skin-tones, hairstyles and dress. Notably Seti I (1294-1279 BC) and Ramesses II (1279-1213 BC) were shown destroying Libyans to the west; Nubians to the south; Bedouin, Canaanites, Syrians and Hittites to the east. ${ }^{18}$ In the time of Ramesses III

\footnotetext{
${ }^{17}$ See Lehmann-Hartleben 1926, op.cit. (n.10), 88-108; 141-144; Hamberg 1945, op.cit. (n. 9), 108119 ; 162-172. For previous comparisons made between Egyptian, Assyrian and Roman documentary reliefs see A. La Regina, 'Ferocia barbarica. La reppresentazione dei vinti tra Medio Oriente e Roma', Jahrbuch des deutschen archäologischen Instituts 109 (1994), 8-26; Fig. 5-22; C.M. Gilliver, The Roman Art of War (London 1999), 67; 131; Fig. 27-28; 49. This is to suggest similar solutions applied to similar iconographic problems, rather than a direct continuity of influence from the second millenium $\mathrm{BC}$ down to the 2nd century $\mathrm{AD}$, although see H.P. Laubscher, 'Zur Bildtradition in ptolemäisch-römischer Zeit', Jahrbuch des deutschen archäologischen Instituts 111 (1996), 225-248.

${ }^{18}$ G. Robins, The Art of Ancient Egypt (London 1997), Fig. 55; 95; 155; 160; 209-210; R. Schulz \& M. Seidel (eds.), Egypt. The World of the Pharaohs (Köln 1998), 34; 40; 124; 163; 165; 169; 190; 322; 369. The bound, standing barbarians on polychrome glazed tiles from Medinet Habu are a particularly evocative set of depictions, rather similar to the barbarians tied to palm trees on the Adamclissi crenellations discussed below (Robins 1997, Fig. 4; Schulz \& Seidel 1998, 396). Commonly the motif of the pharaoh hunting large and dangerous animals was also used as an image of his maintenance of order (ibid., 199 (Seti I); D. Wildung, Egypt from Prehistory to the Romans (Köln 1997), 144 (Ramesses III)). The Roman emperor combating natural forces may similarly be seen in the Hadrianic hunting tondi of the Arch of Constantine in Rome (G. Calcani, 'I tondi dell'arco: Adriano e Costantino', in Adriano. Architettura e Progetto (Milano 2000), 137-147). For
} 
(1183-1152 BC), the Sea Peoples who attacked from the north and west appear on walls at Medinet Habu being bloodily crushed in land migrations and sea battles. ${ }^{19}$ These Egyptian artworks were perhaps seen only by a narrow priestly elite within monumental complexes, but the act of depiction itself had power and thus contributed to a quintessential royal function. Even the militarily inexperienced young pharaoh Tutankhamun was depicted on his funerary furniture riding down barbarian hosts in his chariot. ${ }^{20}$ Thus Egypt was maintained by the pharaoh's military prowess and his relationship with the gods, a centre of order surrounded by barbarian chaos. ${ }^{21}$

The sculptures which decorated the walls of 9th - 7th century BC Assyrian palaces at Nimrud, Nineveh and Khorsabad (Iraq) are another instructive area of monumental art, perhaps one designed to have been seen by a wider audience of courtiers and foreign diplomats. ${ }^{22}$ Elamite, Chaldaean, Samaritan, Bedouin and Egyptian foes are identified by cuneiform inscriptions, but also by dress, hairstyle and equipment. ${ }^{23}$ In particular, conventions were developed to render intelligible significant activities during siege-warfare, and to clearly signal enemy defeat and submission. Similarly, in the Achaemenid palace sculptures of Persepolis in Iran, great lines of tribute-bearers are identifiable by

hunting and modern imperialism see J.M. MacKenzie, The Empire of Nature. Hunting, Conservation and British Imperialism (Manchester 1988).

${ }^{19}$ N.K. Sanders, The Sea Peoples: Warriors of the Eastern Mediterranean, 1250-1150 BC (London 1978), Fig. 1; 66-69; 76-84; 86-93.

${ }^{20}$ Robins 1997, op.cit. (n. 18), Fig. 189; Schulz \& Seidel 1998, op.cit. (n. 18), 240.

${ }^{21}$ For Pharaonic relations with foreigners in general see B. Kemp, 'Imperialism and empire in New Kingdom Egypt', in Garnsey \& Whittaker 1978, op.cit. (n.7), 7-57; 'The Egyptians of the New Kingdom. The enemy as 'non-people", in Carlton 1990, op.cit. (n.7), 34-44; I. Shaw, 'Egypt and the outside world', in I. Shaw (ed.), The Oxford History of Ancient Egypt (Oxford 2000), 314-329. For general studies of the battle reliefs see I. Shaw, 'Battle in ancient Egypt: the triumph of Horus or the cutting edge of the temple economy?', in Lloyd 1996, op.cit. (n.7), 239-269. See now S.C. Heinz, Die Feldzugdarstellungen des Neuen Reiches: eine Bildanalyse (Wien 2001).

22 J.M. Russell, Sennacherib's Palace Without Rival at Nineveh (Chicago 1991), 8: "A survey of Assyrian records....suggests that the potential audience for the neo-Assyrian palace inscriptions included the king and his family, courtiers, Assyrian citizens, foreigners, future kings, and gods". In general see ibid., 223-240; 251-252; J.E. Curtis \& J.E. Reade, Art and Empire (London 1995), $39-$ 42; 92-93; J. Reade, Assyrian Sculpture (London 1998).

${ }^{23}$ Notably R.D. Barnett, Assyrian Palace Reliefs and their Influence on the Sculptures of Babylonia and Persia (London 1960), Pl. 15-16; 33-34; 38; 44-49; 108-128; R.D. Barnett \& M. Falkner, The Sculptures of Tiglath-Pileser III (745-727 BC) (London 1962), Pl. VII; XIV; XXIV; LXX; XCVI; CXVII; R.D. Barnett, Sculptures from the North Palace of Ashurbanipal at Nineveh (668-627 BC) (London 1976), PI. XVII-V; XVIII-XXV; XXVIII-XXX; XXXII-VI; LX-XI; LXVI-XIX; Russell 1991, op.cit. (n.22), Fig. 68-69; 71; 80; 83-84; 89-91; 111; 113; Curtis \& Reade 1995, op.cit. (n.22), No. 4; 13; 20-22; 24-25; Reade 1998, op.cit. (n.22), Fig. 43; 63; 66-68; 90; 96; 98-107. 
their headgear, dress, hairstyle and weapons, and by the nature of their gitts for the King of Kings. ${ }^{24}$ On the other hand, the nine defeated kings who exhibit a range of attires on the Bisitun (Iran) cliff relief of Darius I (c. 520-519 BC) were open to a much wider public scrutiny. ${ }^{25}$

The art and literature of the Greek world also clearly identified 'barbarians' in ways which have been explored by various modern studies. ${ }^{26}$ Greek concern to clearly represent the non-Greek 'other' also manifested itself in visual topoi. Persians, Thracians, Skythians and Africans were distinguished by their ethnic features, dress and weapons. 'Civilised' Greeks went heroically naked whilst barbarians were dressed, the complete opposite of the 17th -20th century colonial-imperialist perception of regular troops in uniforms combating 'naked savages'. Alternatively, Greeks wore characteristic hoplite panoply which imparted an armoured uniformity and, especially with the large hoplite shield, a visual distinction. However, at the same time the wearing of short-sleeved, high-skirted tunics inferred heroic nudity by the exposure of limbs. ${ }^{27} \mathrm{~A}$ general exception to clothed barbarians was the appearance of naked 'Gauls' in Hellenistic art. This is despite the known use of mail armour and helmets by northern peoples, as evidenced by items present, for example, on the Athena Polias precinct colonnade panels from Pergamon (Turkey). ${ }^{28}$ The latter belonged to a genre presenting trophy spolia or congeries armorum which is later much developed under the Roman emperors (discussed below). The communication of these conventions of Greek and barbarian depiction was much more socially inclusive than in the arts of earlier periods previously

\footnotetext{
${ }^{24}$ A.U. Pope, A Survey of Persian Art from Prehistoric Times to the Present (Oxford 1938), Pl. 84; 91-94; 96-98; J. Curtis, Ancient Persia (London 2000), Fig. 50-59. Closely parallelled in prose by Herodotos 7.61-95.

${ }^{25}$ J. Weisehöfer, Ancient Persia from 550 BC to 650 AD (London 1996), Pl. I; Curtis 2000, op.cit. (n.24), Fig. 42.

${ }^{26}$ For example E. Hall, Inventing the Barbarian. Greek Self-Definition Through Tragedy (Oxford 1989); F. Lissarrague, L'autre guerrier. Archers, peltastes, cavaliers dans l'imagerie attique (Paris 1990), 67-149; F. Hartog, The Mirror of Herodotus. The Representation of the Other in the Writing of History (Berkeley 1998).

${ }^{27}$ Clothed barbarians: P. Ducrey, Guerre et guerriers dans la Grèce antique (Paris 1985), Fig. 50; $63 ; 70 ; 73 ; 80 ; 93 ; 144 ; 153-154 ; 166 ; 179 ;$ A. Scholl, 'Der 'Perser' und die 'skythischen Bogenschützen' aus dem Kerameikos', Jahrbuch des deutschen archäologischen Instituts 111 (1996), 79-112. Heroic (semi-)nudity: Ducrey 1985, Fig. 2; 28; 33; 40; 84-87; 95; 142; 145; 166; 190. For the careful distinction of hoplites from other forms of troops by their equipment see Lissarrague 1990, op.cit. (n.26).
} 
discussed. Sculptures, frescoes and floor mosaics ${ }^{29}$ executed primarily for elite viewing were joined in the Classical and Hellenistic periods by massive numbers of lower value painted ceramics and terracottas. ${ }^{30}$

Pre-Trajanic Roman representations of barbarians generally emphasised western adversaries. The indigenous depiction of Spanish warriors with well observed equipment in sculpture, on ceramics, and on coins continued into the later Roman Republican period but did not spread much outside Iberia. ${ }^{31}$ There is some evidence in the form of terracottas from Canosa (Italy) ${ }^{32}$ and other, metal figurines ${ }^{33}$ that a convention of short tunic, small round shield, and corkscrew hair and beard was employed for Numidians. In contrast, and building on Hellenistic conventions, Gauls were depicted naked, but shield-forms, helmets, horns and military standards also played a key part in identification. ${ }^{34}$ Germans were represented wearing trousers and cloak, but not tunic. ${ }^{35}$ Trophies and congeries armorum artworks emphasised the Gallic artefacts but through the 1st century BC to the 1st century $\mathrm{AD}$ the latter were joined by Hellenising elements, such as

\footnotetext{
${ }^{28}$ Ducrey 1985, op.cit. (n.27), Fig. 151-152; 182; R.R.R. Smith, Hellenistic Sculpture (London 1991, Fig. 118-132; E. Polito, I Galati Vinti. Il trionfo sui barbari da Pergamo a Roma (Milano 1999). For 'Celtic' armour see P. Connolly, Greece and Rome at War (London 1981), 120-125.

${ }^{29}$ E.g. N. Jidejian, Sidon (Beirut 1971), Pl. 32-57; M.B. Hatzopoulos \& L.D. Loukopoulos (eds.), Philip of Macedon (Athens 1980), Fig. 49; A. Cohen, The Alexander Mosaic. Stories of Victory and Defeat (Cambridge 1997), Fig. 5-7; 20; 32-35; 66; Smith 2000, op.cit. (n.28), Fig. 226.

${ }^{30}$ See Ducrey 1985, op.cit. (n.27), Fig. 50; 62-63; 70; 72; 75; 80;150; 166; Lissarrague 1990, op.cit. (n.26), Fig. 18; 22; 27; 29-35; 72-74; F. Lissarrague, 'The Athenian image of the foreigner', in T. Harrison (ed.), Greeks and Barbarians (London 2002), 101-124. See also Hall 1989, op.cit. (n.26), 84-86 for the use of ethnic dress as theatrical stage costume.

${ }^{31}$ Discussed in detail with the artefactual record by F. Quesada Sanz, El armament ibérico. Estudio tipológico, geográfico, funcional, social y simbólico de las armas en la cultura ibérica (siglos VI-I a.C.) (Montagnac 1997).

${ }^{32}$ M.I. Rostovtzeff, 'Numidian horsemen on Canosa vases', American Journal of Archaeology 32 (1942), 263-267; Connolly 1981, op.cit. (n.28), 148. Cf. Trajan's Column Scene LXIV and Dio Cassius 68.32.4.

${ }^{33} \mathrm{~N}$. Franken, 'Elefantreiter. Zum Typus der Barbarenstatuette aus Großsachsenheim', Jahrbuch des deutschen archäologischen Instituts 114 (1999), 125-156.

${ }^{34} \mathrm{P}$. Bienkowski, Les celtes dans les artes mineurs Grecs-Romaines avec des recherches iconographiques sur quelques autres peuples barbares (Cracow 1928); I.M. Ferris, Enemies of Rome. Barbarians Through Roman Eyes (Stroud 2000), Fig. 4; 6; 10; 16-18. For modern receptions of these images see T. Champion, 'The power of the picture. The image of the ancient Gaul', in B.L. Molyneaux (ed.), The Cultural Life of Images. Visual Representation in Archaeology (London 1997), 213-229.

${ }^{35} \mathrm{G}$. Girke, Die Tracht der Germanen in der vor- und frühgeschichtlichen Zeit (Leipzig 1922); K. Schumacher, Germanendarstellungen I, Darstellungen aus dem Altertum (Mainz 1935); Ferris 2000, op.cit. (n. 34), Fig. 52; $54 ; 65 ; 69 ; 75 ; 77 ; 84$.
} 
muscled cuirasses, Attic helmets, rostra and even artillery-pieces. ${ }^{36}$ This mix reached its apogee under Domitian with such works as the 'Armilustrum' panels from Rome (now in Firenze) ${ }^{37}$ and the 'Trofei di Mario', also from Rome and now on the Campidoglio (Plates VI, fig. 1) ${ }^{38}$ The great Domitianic altar erected at Ephesos (Turkey) bears the same Hellenising pastiche but with one solitary sword the 'wavy' blade of which may represent a naïve attempt to depict a Dacian falx (see below). ${ }^{39}$

\section{Trajanic realism}

The Trajanic period monuments already mentioned, together with other less complete statues and reliefs of barbarians, represent an extraordinary injection of new iconographic detail. 'New', hitherto unfigured enemies appear. Most notably the congeries armorum on the pedestal of Trajan's Column were purged of Hellenising intrusions, being an accurate, still-life study in stone of barbarian equipment (Pl. VI, fig. 2-3) ${ }^{40}$

The vast majority of enemies on Trajan's Column are identifiable from the context of Trajan's northern wars as Dacians from the Carpathian region (modern Romania). They wear long trousers, long-sleeved tunics with sidesplit skirts, rectangular cloaks and, sometimes, soft 'Phrygian' caps (Pl. VI, fig. $8,11,13,14) .{ }^{41}$ Similar figures on a colossal scale decorated the forum

\footnotetext{
${ }^{36}$ E. Polito, Fulgentibus Armis. Introduzione allo studio dei fregi d'armi antichi (Roma 1998), Fig. $61-62 ; 75 ; 78-81 ; 99-101 ; 108-111 ; 114-118 ; 121-122 ; 126 ; 142 ; 147 ; 153 ; 159$.

37 J.W. Crous, 'Florentiner Waffenpfeiler und Armilustrum', Mitteilungen des Deutschen archäologischen Instituts, Römische Abteilung 48 (1933), 1-119; Polito 1998, op.cit. (n.36), 204, Fig. 146; A. Tempesta, 'I rilievi con armi Cesi: ipotesi di ricomposizione ed interpretazione', Bullettino Comunale 94 (1991-1992), Fig. 19; 20.

${ }^{38}$ S. Reinach, Répertoire de Reliefs Grecs et Romains I, Les Ensembles (Paris 1909), 289-290; E. Nash, Pictorial Dictionary of Ancient Rome (London 1962), II, Fig. 839-840; Ferris 2000, op.cit. (n.34), Fig. 74. The dating of these works (the Firenze panels and the Campidoglio trophies) is almost purely stylistic, as is the attribution of other congeries panels on the Campidoglio (Tempesta 1991-1992, op.cit. (n.37), Fig. 1-2).

${ }^{39}$ If indeed this is not the upper limb of a bow. See E. Lessing \& W. Oberleitner, Ephesos. Weltstadt der Antike (Wien-Heidelberg 1978), Pl. 87; Polito 1998, op.cit. (n.36), 214.

${ }^{40} \mathrm{O}$. Gamber, 'Dakische und sarmatische Waffen auf der Traianssäule', Jahrbuch des Kunsthistorischen Sammlung Wien 60 (1964), 7-34; Polito 1998, op.cit. (n.36), 192-196, Fig. 128-129.

${ }^{41}$ Florescu 1965, op.cit. (n.13), 587-632; Florescu 1969, op.cit. (n.10), 112-117; J. Pinkerneil, Studien zu den Trajanischen Dakerdarstellungen (Freiburg 1983), 80-91. Dio Cassius 68.9.1 noted that aristocratic Dacians were marked by the wearing of caps but, if true, this was not adequately communicated to the Column sculptors. Apart from on Decebalus, caps are shown worn randomly in crowd scenes without regard to wearer's function or status.
} 
complex in which the Column was situated (Pl. VI, fig. 4) ${ }^{42}$ Others are seen on the Great Trajanic Frieze, often with longer skirts. ${ }^{43}$ Such figures appear bound to trees on the crenellations and on some metopes of the Tropaeum Traiani at Adamclissi (Pl. VI, fig. 18) ${ }^{44}$ On the Column the Dacians carry wolfheaded wind-sock standards ('dracones'; PI. VI, fig. 2, 8) ${ }^{45}$

A second type on the Column wears trousers and cloak but, lacking a tunic, is bare-chested and bare-armed. ${ }^{46}$ The hair is twisted up into a knot on the side of the head (PI. VI, fig. 16). These men correspond closely with the Tropaeum Traiani metope figures and other crenellation prisoners, ${ }^{47}$ with the already discussed Germanic barbarian figural type, and with what is known from Tacitus and other iconography of the 'Suebian' German hair-knot (nodus) ${ }^{48}$ There is even one example of a preserved actual knot on a skull from Osterby in Schleswig-Holstein (Germany) ${ }^{49}$ A third type of barbarian, figured in only one Trajan's Column scene (C), wears an ankle-length skirted garment which is also seen on the Adamclissi crenellations (Pl. VI, fig. 12,

\footnotetext{
${ }^{42}$ P. Zanker, 'Trajansforum (Sitzung am 13. Mai 1969)', Archäologischer Anzeiger (1970), 510-512, Fig. 11-18; Pinkerneil 1983, op.cit. (n.41), 124-234; 287-247; R.M. Schneider, Bunte Barbaren. Orientalenstatuen aus farbigen Marmor in der römischen Repräsentationskunst (Worms 1986), 162165; L. Ungaro, 'I Daci', Bullettino Comunale 95 (1993), 145-162; J. Packer, The Forum of Trajan in Rome. A Study of the Monuments (Berkeley 1997), 99; 437-438; Cat. 184-188; J. Packer, The Forum of Trajan in Rome. A Study of the Monuments in Brief (Berkeley 2001), Fig. 61; 143; G.A. Popescu (ed.), Traiano ai confini dell 'impero (Milano 1998), Cat. No. 331-332; M. de Nuccio \& L. Ungaro (eds.), I Marmi Colorati della Roma Imperiale (Venezia 2002), 94-95; 99-100; 128-133; Cat. no. 31-40. For Dacian depictions in general see also G. von Bülow, 'Thrakerdarstellungen in der römischer Kunst', Klio 62 (1980), 145-153; Pinkerneil 1983, op.cit. (n.41), 74-77; 80-96; Ferris 2000, op.cit. (n.34), 61-81.

${ }^{43}$ Leander Touati 1987, op.cit (n.11), Pl. 2-4; 7-8; 13-14.

${ }^{44}$ Florescu 1965, op.cit (n.13), Crenellations V-VIII; XIII-V; XVIII-IX; XXII; XXIV.

${ }^{45}$ Scenes XXIV-V; XXXI, XXXVIII, LIX, LXIV, LXVI, LXXV, CXXII. See J.C.N. Coulston, 'The 'draco' standard', Journal of Roman Military Equipment Studies 2 (1991), 101-114. These also appear on the Column's pedestal reliefs along with 'Celtic' boar's head trumpets (carnyces), for which now see F. Hunter, 'The carnyx in Iron Age Europe', Antiquaries Journal 81 (2001), 77-108.

${ }^{46}$ Scenes XXVII; XXXVIII; C.

${ }^{47}$ Florescu 1965, op.cit (n. 13), Crenellations I; XII; XVII; XXI; XXIII; XXV.

${ }^{48}$ Tacitus, Germania 38; Martialis, Liber de spectaculis 3; H. Fischer, 'Der germanische Nodus und verwantes', Zeitschrift für deutsche Altertum und deutsche Literatur 53 (1912), 183-197; Girke 1922, op.cit (n.35), 3-5, Pl. 31; 38.a, c; Schumacher 1935, op.cit (n.35), No. 87-88; 100; 103-104; 137-138; 142-143; Schleiermacher 1984, op.cit (n.14), No. 20; 22.

${ }^{49}$ P.V. Glob, The Bog People (London 1977), 117-118; Pl. 41.
} 
19) ${ }^{50}$ The garments, split up the front and worn with calf-length riding boots most probably represent long horsemen's kaftans. ${ }^{51}$

The last Column barbarian enemy type is shown shooting a bow from horseback, with both rider and horse entirely encased in scale armour (Scenes XXXI, XXXVII; Pl. VI, fig. 9). These figures are the only armoured barbarians in the whole of Roman art. Asiatic steppe nomad Sarmatians are the only northern barbarians which are regularly described as heavily armoured in Roman literary sources. ${ }^{52}$ The kaftan was a characteristic item of asiatic dress so it is quite likely that the kaftan-wearers on the Column belong to the same group as the armoured cavalry, being shown unarmoured in a non-belligerent, diplomatic context.

On the Column and elsewhere in Trajanic art, notably on coins, Dacians are figured with a characteristic weapon shared by no other people. This is a single or double-handed sword with a wickedly curved blade. Detailed depictions and archaeological finds demonstrate another key characteristic: the blade was single-edged with the sharp edge on the inside of the curve (the opposite of almost all other curved bladed weapons in history, e.g. Thracian sicae and more modern sabres). Roman literature refers to this type of sword as the falx, i.e. 'sickle' or 'scythe', the one term most appropriate for the singlehanded version, the other for the truly murderous two-handed weapon. ${ }^{53}$ On the helical frieze of Trajan's Column only the shorter falx is shown, sometimes with a short grip and guard, sometimes with a long haft (Pl. VI,

\footnotetext{
${ }^{50}$ Florescu 1965, op.cit (n.13), Crenellations II; IV; X-XI; XVI; XXVI. Cf. Fig. 185.

51 A. Pálóczi-Horváth, 'Le costume Coman au moyen age', Acta Archaeologica Academiae Scientiarum Hungaricae 32 (1980), 403-417; E.R. Knauer, 'Ex oriente vestimenta trachtsgeschichtliche Beobachtungen zu Ärmelmantel und Ärmeljacke', Aufstieg und Niedergang der römischen Welt II, Principat 12.3 (Berlin 1985), 578-741; C. Bálint, Die Archäologie der Steppe (Wien 1988), Fig.7.2.

${ }^{52}$ Tacitus, Historiae 1.79; Pausanios 1.21.5-6; Ammianus Marcellinus 17.12.2. For a full discussion of these figures and Sarmatian cavalry in general see J.C.N. Coulston, 'Tacitus, Historiae 1.79 and the impact of Sarmatian warfare on the Roman empire', in C. von Carnapp-Bornhein (ed.), Kontakt - Kooperation Konflikt: Germanen und Sarmaten zwischen dem 1. und 4. Jahrh. $n$. Chr. (Neumünster 2003), 415-433.

${ }^{53}$ Coins: H. Mattingly, Coins of the Roman Empire in the British Museum, III, Nerva to Hadrian (London 1936, henceforth $B M C$ III), Pl. 12.15, 15.6-9, 15.14-15, 28.6-7, 34.1, 35.9, 37.3-6; G.G. Belloni, Le Monete di Traiano. Catalogo del Civico Gabinetto Numismatico, Museo Archeologico di Milano (Milano 1973), No. 50-52, 99-101, 104-107, 270-279, 246-250, 400. Literature: Valerius Flaccus, Achilleid 2.132. Just how potentially destructive this weapon may have been has been demonstrated by D. Sim, 'The making and testing of a falx also known as the Dacian battle scythe', Journal of Roman Military Equipment Studies 11 (2000), 37-41.
} 
fig. 11) ${ }^{54}$ On the Column's pedestal reliefs the full-size weapon is repeatedly depicted (Pl. VI, fig. 3), ${ }^{55}$ as they are on the Adamclissi metopes (PI. VI, fig. $16,17) .{ }^{56}$ Both forms appear in the Transdanubian archaeological record, so clearly there were two types in reality. ${ }^{57}$ The Column sculptors were certainly working from actual artefacts, but the long-hafted, one-handed frieze falces were probably artificially scaled down in size to present them for one-handed use specifically because the pose of a double-handed wielder would have been alien to the rather conservative genre of combat scenes (barbaromachia) ${ }^{58}$

The pedestal reliefs depict piled, captured barbarian equipment in profusion (Pl. VI, fig. 2, 3). In addition to the large falces, the degree of archaeologically verifiable detail is very high so actual spolia were being employed as models for this still-life study in stone. This is a clear link with the public events of Trajan's principate, namely lavish triumphal processions and celebratory games in the capital which form a close link between frontier and centre through the medium of barbarian prisoners and booty (see below).

The attention to ethnic dress has been noted already. The veristic concern with weaponry is also characteristic of imperial receptions of the 'other' in both earlier and later periods. In more modern contexts there has been an emphasis on the frightening effect of wounds inflicted by Scottish Highland broadswords in the Jacobite wars, 'Khyber knives' in the Afghan Wars, and assegais (iklwa) in the Zulu Wars. ${ }^{59}$ In a sense this concern served

\footnotetext{
${ }^{54}$ Scenes LXXII; LXXV; XCV; CXV-VI; CXLIV-V; CLI. See also the falx-blades appearing on trophies in scene LXXVIII. Two double-handed falces are depicted on an honorific pedestal from Amastris (Turkey): A. Büttner, 'Untersuchungen über Ursprung und Entwicklung von Auszeichnungen in römischen Heer', Bonner Jahrbücher 157 (1957), P1. 11.2.

${ }^{55}$ Cichorius 1896-1900, op.cit (n.10), Pl. II-II; Settis 1988, op.cit (n.10), Fig. 20-23. Cf. Polito 1998, op.cit (n.36), Fig. 134; 143.

${ }^{56}$ Florescu 1965, op.cit (n.13), 634, Fig. 184; 195; 197-202; 204; 218; 221. A single-handed falx is depicted on the Adamclissi weapons frieze (Pl. X.C-D).

${ }^{57}$ Short: M. Párducz, Denkmäler der Sarmatenzeit Ungarns II (Budapest 1944), PI. 25.6; C.S. Nicolaescu-Plopsor, 'Antiquités celtiques en Olténie', Dacia 11-12 (1945-1947), Pl. I.6; II.5; IV.7; IV.11; V.11; S. von Schnurbein, 'Ein hölzerne Sica aus dem Römerlager Oberaden', Germania 57 (1979), 122-128; Fig. 9; I. Miclea \& R. Florescu, Geto-Dacii (Bucaresti 1980), Pl. 199; Popescu 1998, op.cit (n.42), Cat. no.285; Long: V. Pârvan, O Protoistorie a Daciei (Bucaresti 1926), Fig. 342. Cf. I. Glodariu \& E. Iaroslavschi, Civilizatia Fierului la Daci (Cluj-Napoca 1979) Fig. 71.1.

${ }^{58}$ Only occasionally do combat figures on the Column depart from accepted canons of pose, as when they throw stones during sieges (CXII; CXV; CXXXIV), and these instances are more closely related to the poses seen in construction scenes (cf. LXVII; LXXVII; XCVI; CXVI).

${ }^{59}$ G.C. Stone, A Glossary of the Construction, Decoration and Use of Arms and Armor (New York 1934), 77; Fig. 97; 354; 355; Fig. 446; A.U.B. Norman, 'Scottish swords of the '45', in Culloden. The Swords and the Sorrows (Edinburgh 1996), 22-53; T.A. Heathcote, The Afghan Wars, 1839-
} 
to make 'native' enemies seem more formidable and savage, thus their overthrow both more admirable and justified.

The general presentation of barbarians on Trajan's Column is as a determined and worthy adversary for Trajan and his army. The achievements of Roman citizen troops are particularly lauded in the areas of building construction, field-craft and siege warfare, quintessentially 'Roman' qualities. ${ }^{60}$ Most of the fighting in the open field is conducted (always with inexorable success) by non-citizen auxiliary troops. Thus the Roman ideal of victory achieved without the loss of Roman blood is advertised throughout and may be closely paralleled in the contemporaneous writings of Tacitus. ${ }^{61}$

The barbarians do wound Roman soldiers, albeit only on one single occasion, and whilst their confusion, indiscipline and fieldcraft incompetence is emphasised throughout (PI. VI, fig. 8), they do keep coming back for more and do attempt 'low-tec' assaults on Roman fortifications. ${ }^{62}$ In one instance wagons appear with a barbarian force (XXXVIII) and it is very likely that this was a deliberate visual-rhetorical device intended to presage disaster. In Roman literature wagons spelt butchery for barbarians who parked their vehicles behind their own army, and then could not escape Roman pursuit through them when they had lost the battle. The Helvetii fought by Caesar and the Britons led by Boudica ${ }^{63}$ suffered in this way; so too did the Bastarnae defeated by Crassus on the Lower Danube in $29 \mathrm{BC}$; and Transdanubian men, women and infants are slaughtered around wagons on the Adamclissi metopes (PI. VI, fig. 17) ${ }^{64}$ Wheeled transport figured in

1919 (London 1980), 51; I. Knight, The Anatomy of the Zulu Army from Shaka to Cetshwayo, 18181879 (London 1995), 109-113; C. Spring, African Arms and Armour (London 1993), 127; Fig. 121.

${ }^{60}$ J.C.N. Coulston, 'The architecture and construction scenes on Trajan's Column', in M. Henig (ed.), Architecture and Architectural Sculpture in the Roman Empire (Oxford 1990), 39-50; J.C.N. Coulston, 'Travel and transport on the Column of Trajan', in C. Adams \& R. Laurence (eds.), Travel and Geography in the Roman Empire (London 2001), 126-130.

${ }^{61}$ Tacitus, Agricola 35. See J.C.N. Coulston, 'The value of Trajan's Column as a source for military equipment', in C. van Driel-Murray (ed.), Roman Military Equipment: the Sources of Evidence. Proceedings of the Fifth Roman Military Equipment Conference (Oxford 1989), 32.

${ }^{62}$ Incompetent river-crossing XXXI. Fort assaults XXXII; XCIV-VI; CXXXIV. Wounded Roman soldiers XL. The latter scene served to demonstrate both civilised Roman medical capabilities and the emperor's concern for the well-being of his soldiers (cf. Dio Cassius 68.8.2), rather than to emphasise barbarian prowess. See R. Jackson, Doctors and Diseases in the Roman Empire (London 1988), 126-137; P.A. Baker, 'Medicine, culture and military identity', in Fincham et al. 2001, op.cit (n.4), 48-68.

${ }^{63}$ Caesar, De bello Gallico 1.24; 26; Tacitus, Annales 14.37; Dio Cassius 62.12.5.

${ }^{64}$ Dio Cassius 51.24.4; Florescu 1965, op.cit (n.13), Fig. 218-221. 
Egyptian sculpture, notably when a land-migration of Sea Peoples is crushed in sculptures on the walls of Medinet Habu. ${ }^{65}$ Dead horses, overturned vehicles and stray wheels also served to denote destruction of adversaries in Assyrian works. ${ }^{66}$ Faced with such disastrous defeat, the Dacians in one great set-piece scene on Trajan's Column seem to commit suicide en masse by drinking poison to cheat humiliating capture (CXX-XXI; Pl. VI, fig. 13) ${ }^{67}$ Ultimately, the barbarian king, Decebalus, cuts his own throat rather than become the star attraction of a Trajanic triumphal procession in Rome (CXLV; Pl. VI, fig. 14) ${ }^{68}$ 'Suicide before dishonour' was a noble course in accord with a stoic Roman ethos, elevating the practitioners to a high level of regard. Conversely, it could be interpreted as a desperately savage escape, denoting cowardice and lack of character. ${ }^{69}$

Otherwise the behaviour of barbarians is not depicted as particularly 'barbaric'. On the contrary, to modern eyes, especially those of 'imperialist' apologists, there are some uncomfortably barbaric Roman practices. On occasion barbarians are decapitated by soldiers in the heat of battle (CXIII). Once an auxiliary fights whilst the hair of a severed Dacian head is clamped between his teeth (XXIV; PI. VI, fig. 6) ${ }^{70}$ In other scenes on the Column frieze non-citizen soldiers present severed barbarian heads directly to Trajan (XXIV, LXXII; Pl. VI, fig. 5). This has been explained away by modern

\footnotetext{
${ }^{65}$ Sanders 1978, op.cit (n. 19), Fig. 76-78.

${ }^{66}$ Barrett 1960, op.cit (n.23), P1. 119; 121; 129; Reade 1998, op.cit (n.22), Fig. 96.

${ }^{67}$ Although this scene has also been interpreted as one depicting water being rationed out and the effects of thirst. See Froehner 1872-1874, op.cit (n.10), 22; Cichorius 1896-1900, op.cit (n.10), III, 262; E. Petersen, Trajans dakische Kriege (Leipzig 1899-1903), II, 100; Lehmann-Hartleben 1926, op.cit (n.10), 117; W. Gauer, Untersuchungen zur Trajanssäule (Köln 1977), 38; Lepper \& Frere 1988, op.cit (n.10), 168-169; Settis 1988, op.cit (n.10), 176-186; 486; La Regina 1994, op.cit (n.17), 27. Dacians are definitely seen to be killing each other with swords in scene CXL, and parallels may be drawn with Chaldaeans stabbing each other on an Assyrian relief from Nineveh (Barnett 1976, op.cit (n.23), Pl. XXXIV), and with the statue of a Galatian driving a sword into his own breast from Rome (Polito 1999, op.cit (n.28), 61-63). For barbarian suicide see N.F. Parise, 'Galati suicidi. Onore e morte presso i Celti', Origini 15 (1990-1991), 369-374 (this article has not been seen by the present writer).

${ }^{68}$ Plinius Minor, Epistulae 8.4.2; Dio Cassius 68.14.3. See M.P. Speidel, 'The captor of Decebalus, a new inscription from Philippi', Journal of Roman Studies 60 (1970), 142-153.

${ }^{69}$ Cf. Appianos, 6.97, 8.131; Josephos, Bellum Iudaicum 7.389-398; Dio Cassius 65.6.3; Symmachus, Epistulae 2.46. On Roman suicide see P. Plass, The Game of Death in Ancient Rome. Arena Sport and Political Suicide (Madison 1995).

${ }^{70}$ A practice only parallelled to the writer's knowledge in Japanese art. Cf. a print reproduced in J. Newman, Bushido. The Way of the Warrior. A New Perspective on the Japanese Military Tradition (Wigston 1989), 160.
} 
commentators as a 'non-Roman' practice greeted with a pained expression from the emperor."

One is vividly reminded by an incident related by Field-Marshall Viscount Slim which took place during the Burma campaign of the Second World War. The British and Empire forces had been swept out of Burma by the Japanese, but then had started to regroup and retrain, and had commenced aggressive patrolling back into contact with the enemy:

Our men brought back a Japanese rifle, an officer's shoulderstraps, a steel helmet. Sometimes they brought back even more convincing exhibits as did the Gurkhas who presented themselves before their general, proudly opened a large basket, lifted from it three gory Japanese heads, and laid them on his table. Then they politely offered him for dinner the freshly caught fish which filled the rest of the basket. ${ }^{72}$

Mutilation of the fallen was a practice common to many cultures for the purposes of ritual, retribution, or just for enumerating the enemy dead. ${ }^{73}$ The piles of amputated hands or severed, uncircumcised penises in Egyptian artworks, ${ }^{74}$ and the severed heads and impaled bodies in Assyrian reliefs are

\footnotetext{
${ }^{71}$ This is discussed at length by A.K. Goldsworthy, The Roman Army at War, $100 B C-A D 200$ (Oxford 1996), 271-273, with emphasis on head-taking being an auxiliary rather than a citizensoldier practice. See also J. Webster, 'Ethnographic barbarity: colonial discourse and 'Celtic warrior societies", in Webster \& Cooper 1996, op.cit (n.1), 117-118.

${ }^{72}$ W.J. Slim, Defeat into Victory (London 1999), 188.

${ }^{73}$ For example, Zulu warriors opened up the stomach cavity of a dead enemy as part of expiation for the act of killing, to release the dead warrior's spirit, and to avoid ritual contamination. Some degree of mutilation is almost inevitable when bladed weapons are used face-to-face in war, not least because multiple stabbing or frenzied hacking in the heat of combat would continue until an enemy was obviously dead. Dropping an enemy with a bullet at a distance might be seen as more clinical. Zulu warriors coming up behind those first in combat would stab the wounded/dead in order to ritually share in the killing, as in a lion-hunt, and thus British observers were shocked by the multiple assagai-wounds (Knight 1995, op.cit (n.59), 224-226).

${ }^{74}$ Sanders 1978, op.cit (n.19), Fig. 11; Robins 1997, op.cit (n.18), Fig. 25; Schulz \& Seidel 1998, op.cit (n.18), 29; 368. In a world where only the Egyptians were circumcised, the use of severed enemy penises for counting the dead was particularly effective from the scribes' point of view if they did not trust the soldiers' claims. Severed hands taken from Egyptian civilians, women and dead colleagues could have allowed Egyptian troops to inflate their achievement and increase the 'bodycount'. The latter tendency has been seen during modern wars, notably in Vietnam.
} 
sanguinary and graphic versions of such traits in pictorial commemoration. ${ }^{75}$ The recumbent but intact bodies below the feet of Achaemenid kings are a more symbolic rendition of defeated leadership. ${ }^{76}$

In the Roman context the state took the heads of traitors and displayed them in public, particularly in the Forum Romanum. ${ }^{77}$ In another scene on Trajan's Column citizen troops work with barbarian heads impaled on poles in the background (LVI; Pl. VI, fig. 10). Citizen troops on the Great Trajanic Frieze again present heads to Trajan (Pl. VI, fig. 15). ${ }^{78}$ After Decebalus committed suicide (CXLV) his head was struck off, displayed to the army (CXLVII), and sent to Rome for display and disposal. ${ }^{79}$ This was a very potent public proof of victory, second only to leading an enemy leader, be he Hellenistic king or barbarian chieftain, through the streets of Rome during the victor's triumph, then executing him below the capitol as a form of human sacrifice. How very different from the fate of the Zulu King Cetshwayo, sent as a prisoner to London in 1882 to take luncheon with Queen Victoria. $^{80}$

Polybios wrote a chilling account of the disciplined ferocity of the Roman soldiers who sacked Carthago Nova in 209 BC. Killing everything,

\footnotetext{
${ }^{75}$ Barnett \& Falkner 1960, op.cit (n.23), Pl. XIV; XVII; XXXIV; XXXVIII-XL; XLIV; XLIX; LVIIIIX; LXXVIII; Barnett 1960, op.cit (n.23), Pl. 38; 40; 119; 128; 130-131; Barnett 1976, op.cit (n.23), Pl. XXII; XXIV-V; LXVII; Russell 1991, op.cit (n.22), Fig. 67-69; 72; 77; Curtis \& Reade 1995, op.cit (n.22), No. 11; 22; Reade 1998, op.cit (n.22), Fig. 75.

${ }^{76}$ Curtis 2000, op.cit (n.24), Fig. 42; 88; 90 . See also Barnett \& Falkner 1962, op.cit (n.23), Pl. XCV-VI.

${ }^{77}$ The fate of Cicero's head and hands placed on the Rostra is a case in point (Plutarch, Cicero 48.449.1) but there were other infamous occasions under the principate: Dio Cassius 63.6.4-5 (Galba, Piso etc.); 64.21 .2 (Vitellius); Tacitus, Historiae 3.74 (Sabinus). Galba was decapitated specifically by a soldier (Suetonius, Galba 20.2). The heads of Domitian's victims were displayed in the Forum (Dio Cassius 67.11.3).

${ }^{78}$ Leander Touati 1987, op. cit .(n.11), Pl. 3-4; 13-14; 32.1-4. For identification of all the troops on the great Trajanic Frieze as praetoriani see J.C.N. Coulston, “Armed and belted men': the soldiery in imperial Rome', in J. Coulston \& H. Dodge (eds.), Ancient Rome: the Archaeology of the Eternal City (Oxford, 2000), 92; 98-99. This identification, based in part on the presence of scorpion blazons on helmets and shields, has now been independently applied to other sculptures by another commentator (H.I. Flower, 'A tale of two monuments: Domitian, Trajan, and some praetorians at Puteoli (AE 1973, 137)', American Journal of Archaeology 105 (2001), 636). For other decapitations by troops see Livy 24.15; Caesar, De bello Hispaniensi 32. For a severed head being brandished by a Roman cavalryman on an Adamclissi metope see Florescu 1965, op.cit (n.13), Fig. 183.

${ }^{79}$ Dio Cassius 68.14.3; Fasti Ostienses $\mathrm{AD}$ 106; A. Fraschetti, 'Traiano nei fasti Ostienses', in G. González, Trajano. Emperador de Roma (Roma 2000), 151.

${ }^{80}$ Execution: Josephus, Bellum Iudaicum 7.153-154. For Cetshwayo see D.R. Morris, The Washing of the Spears (London 1968), 601.
} 
including dogs, they stopped to the order of a trumpet call. This was inhuman in a way quite different from the predictably unrestrained behaviour of northern barbarians. ${ }^{81}$ This was bad enough, but when a regular army, selfconsciously representing 'civilisation', warred with 'primitives' or 'barbarians', then torture and mutilation practices might be delivered as retribution by both sides. The 'civilised' party could justify any actions as revenge and as fitting treatment of 'savages'. This seems to have been the situation with scalping in 17th and 18th century America. It could be justified as a native practice fittingly adopted as a response to Amerindian (and Canadian white enemy) practices. $^{82}$ Similarly, the 19th century conflicts between native tribes and the U.S. Cavalry saw appalling activities carried out by all parties, including not only scalping but also the mounting of severed heads on polls for display and intimidation. ${ }^{83}$ In Scene XXV on Trajan's

\footnotetext{
${ }^{81}$ Polybios 10.15.4-8, especially noting butchery which even included cutting dogs in half. As an image of purposeful ferocity this is very vivid, but when massacres do occur there may be an almost atavistically savage concern to kill all life associated with the vanquished. Amerindians are reported to have killed everything on 19th century settler farms, including dogs, cats, chicken and ducks (T. Goodrich, Scalp Dance. Indian Warfare on the High Plains, 1865-1879 (Mechanicsburg 1997), 302). At My Lai (Vietnam) in 1968 U.S. troops killed old men, women and babies, but also water buffaloes, pigs and chickens, stuffing their carcasses down wells to poison the water (N. Sheehan, $A$ Bright Shining Lie. John Paul Vann and America in Vietnam (London 1990), 689-690). The socalled 'war cemetery' in the native oppidum at Maiden Castle (Dorset) may no longer be interpreted as an archaeological record of the Roman army's fury visited on defenders. Contrast R.E.M. Wheeler, Maiden Castle, Dorset (London 1943), 61-65 with N.M. Sharples, Maiden Castle. Excavations and Field Survey, 1985-1986 (London 1991), 119-125. See also J.C.N. Coulston, 'The archaeology of Roman conflict', in Freeman \& Pollard 2001, op.cit (n.7), 36.

${ }^{82}$ The taking of scalps was practiced both by native Americans and by white settlers (even sometimes by settler women), but by offering inflated bounties for scalps settler authorities encouraging both the practice by all parties and the preying by whites on 'friendly' native groups (I.K. Steele, Warpaths. Invasions of North America (Oxford 1994), 131; 146-147; 162; 228; A. Starkey, European and Native American Warfare, 1675-1815 (London 1998), 12-13; 30-31). Major General James Wolfe addressed scalping with regard to British Crown forces in a general order: "The Genl. strictly forbids the inhuman practice of scalping, except when the enemy are Indians, or Canads. dressed as Indians" (quoted in F. Anderson, Crucible of War. The Seven Years War and the Fate of Empire in British North America, 1754-1766 (London 2000), 788-789). The question of who first practiced scalping has been effectively resolved by finds at the 14th century Crow Creek Massacre site (South Dakota, U.S.A.). Here almost $90 \%$ of 486 individuals in a mass grave exhibited cranial scalping cuts (L.J. Zimmerman, 'The Crow Creek Massacre: archaeology and prehistoric plains warfare in contemporary contexts', in Carman, 1997, op.cit (n.7), 75-94).

${ }^{83}$ Goodrich, 1997, op.cit (n.81), 4; 9-10; 13-14; 18; 29-30; 66; 72-74; 147-148; 190; 260-261. R.A. Fox, Archaeology, History, and Custer's Last Battle. The Little Big Horn Reexamined (Norman 1993), 221: "Archaeological results, in instances where sufficient human remains existed (at the Little Big Horn site), testify to decapitation and dismemberment. Acts of mutilation were, in part, a
} 
Column a Dacian fortification is decorated with impaled skulls. Presumably these were Roman, so both sides were decapitating for effect, and the early occurrence of the scene perhaps further served to suggest that the Roman invasion of Dacia was justified by previous barbarian 'crimes, ${ }^{84}$

Concentration on the atrocities of adversaries, attention to their characteristic weaponry (e.g. 'war-clubs', 'tomahawks' etc., see above), and use of a related language of abuse ('hell-hounds', 'savages', 'fiends' etc.), served in many historical contexts to further demonise a 'primitive' enemy. This could have the unfortunate effect of inculcating a particular dread of capture and torture in 'civilised' forces. This was the case with the Aztec sacrifice and mutilation of conquistador prisoners. ${ }^{85}$ Likewise, the expectations of white settlers and soldiers were bleak with regard to their treatment as captives by Amerindian enemies. Native women were accounted as particularly savage, thus counterbalancing the 'outraging' of white women with the sexual mutilation of white men. ${ }^{86} \mathrm{~A}$ 'save the last bullet for yourself'

result of anger and were a practice not restricted to one or other group (native or white). But the Indian way also required mutilation for cultural and spiritual reasons. Maimed enemies could not confront you in the hereafter. Also, certain marks on a body showed the ethnic identity of the one who had killed an enemy".

${ }^{84}$ La Regina 1994, op.cit (n.17), 31-34 specifically links the justification of head-taking of XXIV with the Roman heads in XXV, citing Florus 1.39.7. A poetic parallel to Roman remains in barbaricum is the reference to Comelius Fuscus' entrails being a feast for Dacian vultures (Juvenal, Satirae 4.111-112). According to Frontinus, Stratagemata 2.9.4 the German leader Arminius displayed Roman heads on poles outside a camp to intimidate the Roman occupants. Similar Roman use of heads for morale purposes is recorded (ibid. 2.9.2-5; Dio Cassius 51.25.4). Two Adamclissi metopes depict severed barbarian heads alongside corpses (Florescu 1965, op.cit (n. 13), Fig. 212-213).

${ }^{85}$ R. Hassig, Mexico and the Spanish Conquest (London 1994), 135-136: "Ten of the Spanish captives were taken to the Great Temple and sacrificed. Their severed heads were then sent to the battlefront and thrown at the Spaniards, which must have demoralized them. After the Spaniards withdrew to their camps for the night, they could hear the drums from the Great Temple and see the other captured Spaniards being made to dance in front of the image of the Aztec god Huitzilopochtli before their hearts were cut out. Aside from religious significance, the Spaniards were sacrificed for psychological impact, both on Cortes' forces and on the Aztecs' allies. The sacrificed Spaniards were flayed and their faces - beards attached - were tanned and sent to allied towns as tokens of Aztec success, as proof of Spanish mortality, and in order to solicit assistance and to warn against betraying the alliance".

${ }^{86}$ Goodrich 1997, op.cit (n. 81$), 3 ; 43 ; 115-130 ; 133 ; 155-158 ; 300-303$. It is important to mention in this connection Trajan's Column Scene XLV. This depicts naked and bound men being tortured by women with torches. The victims have been identified both as Romans and as Dacians (Froehner 1872-1874, op.cit (n.10), 13; Cichorius 1896-1900, op.cit (n.10), II, 217; Petersen 1899-1903, op.cit (n.67), I, 48; Lehmann-Hartleben 1926, op.cit (n.10), 118-119; R. Paribeni, Optimus Princeps. Saggio sulla storia e sui tempi dell 'imperatore Traiano (Messina 1926-1927), I, 100; Gauer 1977, op.cit (n.67), 28, n.144; R. Vulpe, 'Prigionieri romani suppleziati da donne dacie sul rilievo della 
mentality may have marked Roman behaviour on various occasions. ${ }^{87}$ In particular, in $\mathrm{AD} 9$ Roman soldiers killed each other or fell on their own swords to escape the tortures and human sacrifice practiced on prisoners by the Germans. ${ }^{88}$ In reality there would have been a very fine line between suicide to avoid the dishonour of capture, and to escape both the pain and the dishonour of 'breaking' under torture. Yet it is important to hold firmly onto the realisation that Roman literature and iconography presented a barbarian image which was both expected and shared by Roman metropolitan society. Just as in more recent periods, presentation of the barbarian 'other' as inherently bellicose and prone to savage acts suited an audience in the capital, detached from daily realities on and beyond the frontiers. The danger lies in modern commentators believing that the image was also the reality. ${ }^{89}$

There is no doubt that Trajan's Column was a landmark project in its own right, and that its innovative elements of design and iconography had a profound influence on subsequent monuments. Echoes of its pedestal reliefs appear until the end of the 2 nd century, although with increasing stylisation and intrusion of 'classical', Hellenising equipment items amongst the evermore bland barbarian pieces. For example, one heavily restored relief in the Townley Collection of the British Museum was clearly modeled on Trajan's

Colonna Traiana', Rivista Storica dell'antichità 3 (1979), 109-125; Hannestad 1986, op.cit (n.9), 162; Lepper \& Frere 1988, op.cit (n.10), 90; Settis 1988, op.cit (n.10), 175; Goldsworthy 1996, op.cit (n.71), 262, n.49). It is unlikely in the extreme that, in the Column's panegyric of emperor and army, Romans would have been depicted as left by Trajan to die horribly in captivity by barbarian hands. This scene is more likely concerned with salutary punishment dealt out to barbarians by provincials, in stark contrast to the preceding scene of Trajan rewarding his soldiers (XLIV). See Coulston 1990, op.cit (n.10), 296-297.

${ }^{87}$ Caesar, De bello Gallico 5.37; Tacitus, Annales 4.73; Josephus, Bellum Iudaicum 6.186-187. See Goldsworthy 1996, op.cit (n.71), 262-263. For 'save the last bullet' and U.S. Cavalry officers shooting each other to avoid capture see Goodrich 1997, op.cit (n.81), 30; 43. For the disgrace of a Roman soldier who allowed himself to be captured see Josephos, Bellum Iudaicum 6.359-362.

${ }^{88}$ Ovidius, Tristia 4.2.35-36; Florus 2.30.37-39; Tacitus, Annales 1.61; Dio Cassius 56.18.22.1. See Coulston 2001, op.cit. (n.81), 28-31. It may be, of course, that suicide in these circumstances had become a literary topos, and that most, if not all, of the details in non-contemporary historical narratives are metahistorical.

89 'Barbarian' behaviour such as that mentioned by Florus 1.39.2; Tacitus, Annales 14.33; Agricola 16.1; Dio Cassius 62.7.1-3 (Cf. Said 1993, op.cit (n.2), 177). The traditional views of 'the Celts' are now being radically re-evaluated in the light of post-colonial discourse. Contrast M.J. Green (ed.), The Celtic World (London 1995), ch. 3-4 with Webster 1996, op.cit (n.71), 111-123; K. Randsborg, 'Into the Iron Age: a discourse on war and society', in Carmen \& Harding 1999, op.cit (n.7), 191202; S. James, The Atlantic Celts. Ancient People or Modern Invention? (London 1999); G. Carr \& S. Stoddart (eds.), Celts from Antiquity (Cambridge 2002). 
Column spolia, but an Attic helmet and a muscled cuirass have crept in as classicising elements. ${ }^{90}$ An Antonine pedestal, now at Frascati, likewise follows the Column but with additional intrusions. ${ }^{91}$

For many aspects of the study of Trajan's Column it is often very instructive to compare and contrast it with the other great 2nd century figural monument to survive in Rome, the Column of Marcus Aurelius, which was both an emulation of, and an improvement on, Trajan's Column. Comparison back and forth between the two spiral friezes is very instructive on layout, composition and sculpting. There are different Danubian barbarian enemies on the Marcus Column where the bare-chested Germanic type is combined in larger numbers than on Trajan's Column with a new German type which wears a long-sleeved tunic. The latter is rather like the Trajanic Dacian type but seldom wears a cap. Despite the fact that Marcus' wars were against Sarmatians as well as German Marcomanni and Quadi, no armoured barbarian cavalry or wearers of kaftans are present. Overall, the characterisation of barbarians, in line with the general paucity of detail on the Marcus Column, is far more bland than on earlier monuments. There are no barbarian military standards, for example.

What is most striking is the contrast with Trajan's Column in the general treatment of the barbarians on the Marcus Column. Villages are burnt much more frequently, people are literally dragged off into slavery, and women are directly abused. Some are pulled by the hair (XX) and in at least one scene (XCVII) women are being stabbed to death. Indeed, the slaughter of barbarians is not simply widespread but depicted with a violence and detail bordering on relish! Prisoners are speared and literally trodden underfoot (LXVIII) ${ }^{92}$ Others are forced to decapitate their bound brethren whilst Roman guards look on implacably. ${ }^{93}$

\footnotetext{
${ }^{90}$ A.H. Smith, A Catalogue of the Sculpture of the Department of Greek and Roman Antiquities, British Museum (London 1904), Fig. 69; S. Reinach, Répertoire des reliefs grecs et romains II. Afrique. Îles Britanniques (Paris 1912), 497, Fig. 1; Tempesta 1991-1992, op.cit (n. 37), 312-316; Fig. 4-5.

${ }^{91}$ Polito 1997, op.cit (n.36), Fig. 144. For other reliefs which include falces, banded armour and other features exhibited on the pedestal of Trajan's Column see Tempesta 1991-1992, op.cit (n.37), Fig. 18; 23; Polito 1997, op.cit (n.36), Fig. 127; 134; 143.

${ }^{92}$ Women are comparatively well treated on Trajan's Column, and Scene XXX has even been interpreted as depicting Trajan showing clementia to Decebalus' sister, with refence to Dio Cassius 69.9.4 (R. Vulpe, 'Capturarea surorii lui Decebal', Sargetia 4 (1966), 75-96). Perhaps a further citation was being made to the good treatment afforded to Darius III's mother and other women by Alexander the Great (Arrianos, Anabasis 2.11.9; 12.3-8. Cf. Dio Cassius 68.15.1; 68.26.4; 68.29.1; 68.30.1). For women on Trajan's Column see N. Boymel- Kampen, 'Looking at gender: the Column of Trajan and Roman historical relief', in D.C. Stanton \& A.J. Stewart (eds.), Feminisms in the
} 
Thus an ongoing process of barbarian genericisation may be traced into the later 1st century $\mathrm{AD}$, until a massive influx of new and veristic barbarian types and details occurred under Trajan. These new details of dress and equipment tailed away in the course of the 2nd century, and for the rest of the Roman period essentially two bland types existed to represent all barbarians, both eastern and western. These were the bare-chested German, and the fully clothed men who served as Dacians, Danubian Germans, and even as Parthians (as on the Arches of Septimius Severus) ${ }^{94}$ Even without a detailed analysis of post 2 nd century barbarian representations, it is clear that

Academy (Ann Arbor 1995), 46-73. Marcus Column destruction of villages: VII; XVIII; XX; XLII; XLVI; XCVIII; CII; CIV. Villages or individual buildings are rarely burnt by Roman troops on Trajan's Column (XXV; XXIX; LIX; CLIII), sometimes by Dacians as they retreat (CXIX). The army is presented as an agent of construction rather than destruction. For comparable scenes in Assyrian sculpture see Barnett 1960, op.cit (n.23), Pl. 114; 132; Barnett 1976, op.cit. (n.23), Pl. XXXIII. In reality ancient warfare generally involved destruction visited on an entire enemy population, and the lands of hostile tribes would have been ravaged by the Roman army, in part for campaign supplies, in part as retribution (Goldsworthy 1996, op.cit (n.71), 290-291; P. Erdkamp, Hunger and the Sword. Warfare and Food Supply in the Roman Republican Wars (264-30 BC) (Amsterdam 1998), 122-140; J.P. Roth, The Logistics of the Roman Army at War (264 BC-AD 235) (Leiden 1999), 130-134; Gilliver 1999, op.cit (n. 17), 60-61; Coulston 2001, op.cit (n.60), 118-119). This is of course true of modern warfare where atrocities act as an instrument of policy, or result from a lapse in regular army discipline, with or without the compliance of officers. Notable examples would be the massacres at Sand Creek (1864) and Wounded Knee (1890) of Amerindian villagers by cavalry troops (Goodrich 1981, op.cit (n.81), 3-4; 48; 52; R.H. Dillon, North American Indian Wars (Greenwich 1983), 144; 250; D. Brown, Bury My Heart at Wounded Knee. An Indian History of the American West (London 1991), 87-94; 439-445; Freeman \& Pollard 2001, op.cit (n.7), 194-198). In these cases there was an eastern public opinion to be outraged, whereas in Rome such actions would have been thought justified. It is interesting that the two 'Western' films which drew on the Sand Creek Massacre for material (Soldier Blue, U.S.A., 1970; Little Big Man, U.S.A., 1970) appeared soon after the 1968 My Lai Massacre (Vietnam) which likewise appalled public opinion. Edward Said appositely highlights the part played by presentation of the 'other' to a home audience: "One must remember, too, that when one belongs to the more powerful side in the imperial and colonial encounter, it is quite possible to overlook, forget, or ignore the unpleasant aspects of what went on 'out there'. The cultural machinery - of spectacles like Aida, of the genuinely interesting books written by travellers, novelists, and scholars, of fascinating photographs and exotic paintings - has had an aesthetic as well as informative effect on European audiences. Things stay remarkably unchanged when such distancing and aestheticising practices are employed, for they split and then anaesthetise the metropolitan consciousness" (Said 1993, op.cit (n.2), 157). Cf. R.T. Stearn, 'War correspondents and colonial war', in J.M. MacKenzie (ed.), Popular Imperialism and the Military, 1850-1950 (Manchester 1992), 139-161.

${ }^{93}$ Scene LXI.

${ }^{94}$ R. Brilliant, The Arch of Septimius Severus in the Roman Forum, Memoirs of the American Academy in Rome 29 (Roma 1967), Pl. 49-59; 78a-b; 79; 82a; 83a; 95. 
the Trajanic period saw extraordinary iconographic developments centred on the Forum of Trajan complex and related metropolitan monuments.

It is possible to identify the barbarians in Trajanic sculpture because of the close attention paid to dress, weaponry and equipment. Indeed, a combination of Trajan's Column and other monuments in Rome, with iconography from the frontiers of the empire, with archaeological evidence for the cultures of the Danubian region, and with Roman historical, geographical and ethnographic writings, allows the enquiry to explore very specific identifications.

The bulk of the barbarians depicted in Rome were surely Decebalus' Dacians living within his Carpathian kingdom (Pl. VI, fig. 8, 13). The Germans on Trajan's Column have been identified as Buri (Pl. VI, fig. 7, 12) ${ }^{95}$ Those on the Adamclissi sculptures were most likely Bastarnae who were the Germans located opposite Moesia and closest to that monument (PI. VI, fig. 16) ${ }^{96}$ Armoured cavalry and kaftan-wearers were Sarmatian steppe nomads: perhaps those meeting Trajan peacefully were from the western Sarmatian Iazyges who seem to have been pro-Roman, or at least quiescent during Trajan's principate (P1. VI, fig. 12); ${ }^{97}$ those in armour on the Column or presented as bound prisoners at Adamclissi were more likely eastern Sarmatian Roxolani (P1. VI, fig. 9, 19). ${ }^{98}$ One Adamclissi type of barbarian remains to be identified: the men wearing trousers alone, wielding the doublehanded falx, and travelling with wagons (Pl. VI, fig. 16, 17). Relevant here is the funerary inscription which records the activities of a Neronian governor of Moesia Inferior, Ti. Plautius Silvanus (Ponte Lucano, Italy). ${ }^{99}$ This text took great care to identify the different peoples Silvanus dealt with (Bastarnae, Daci, Rhoxolani, Sarmatae, Scythi) but simply referred to people translocated

\footnotetext{
${ }^{95}$ Tacitus, Germania 43; Dio Cassius 68.8.1; 72.18; 73.2.4; SHA, Marcus 22. See R. Vulpe, 'Les Bures alliés de Décébale dans la première guerre dacique de Trajan', Studii Classice 5 (1963), 223247; R. Vulpe, 'Dion Cassius et la campagne de Trajan en Mésie Inférieure', Studii Classice 6 (1969), 205-232.

${ }^{96}$ Tacitus, Germania 46; SHA, Marcus 22; Dio Cassius 51.23.2-3; 26.5; ILS 986.

${ }^{97}$ Dio Cassius 68.10.3.

${ }^{98}$ For the Sarmatian peoples and their relations with Rome and her neighbours see T. Sulimirski, The Sarmatians (London 1970); J.J. Wilkes, 'Romans, Dacians and Sarmatians in the First and Early Second Centuries', in B. Hartley \& J. Wacher (eds.), Rome and Her Northern Provinces (Gloucester 1983), 269-270; 273-274; U. Müller, Der Einfluss der Sarmaten auf die Germanen (Bern 1998); M. Mielczarek, The Army of the Bosporan Kingdom (Lódz 1999), 28; 82-83; 86-98; Coulston forthcoming, op.cit (n.52).

${ }^{99}$ ILS 986; P. Conole \& R.D. Milns, 'Neronian frontier policy in the Balkans: the career of Ti. Plautus Silvanus', Historia 32 (1983), 183-200; Wilkes 1983, op.cit (n.98), 259-260; 268.
} 
to the Roman province as 'transdanuviani'. Perhaps this epithet was applied to migrant occupants of the plains south and east of the Carpathians, people not recognised by Roman commentators as having been specifically linked by culture or political subservience to the other named groupings. Thus Trajan's Column represents the main Dacian enemy under Decebalus, with some Sarmatians and Germans appearing as less prominent adversaries of Rome, or as emissaries. On the other hand, the Adamclissi tropaeum depicts local enemies, non-Decebalan Dacians, Sarmatian Roxolani, Germanic Bastarnae and Transdanubian migrants. In all this discussion of 'identities' it is fully realised that the ethnonyms found in the ancient sources were the labels employed by the Romans to simplify and rationalise the complex mosaic of diplomacy, ethnicity and culture in the Danubian region. ${ }^{100}$

\section{The trajanic context}

Trajan's Column was an integral part of the Forum Traiani complex. ${ }^{101}$ Past attempts to show that it was a secondary element, that it originally occupied a different position, or that the helical frieze was a post-Trajanic addition have

\footnotetext{
${ }^{100}$ Sometimes the use and authority for such labels was overtly discussed, as in the case of 'Dacians' (Dio Cassius 67.6.2). Sometimes Graeco-Roman writers were aware of the culture change of various groups over time, as with the Bastarnae (Livy 40.57; Dio Cassius 51.23; Strabo, Geographia 7.3.15; 7.3.17; Tacitus, Germania 46). See E. Demougeot, 'L'image officielle du barbare dans l'Empire romain d'Auguste à Théodose', Ktema 9 (1984), 123-143; K.J. Matthews, 'Britannus/Britto: Roman ethnographies, native identities, labels, and folk devils', in A. Leslie (ed.), Theoretical Roman Archaeology and Architecture (Glasgow 1999), 14-32; P.S. Wells, Beyond Celts, Germans and Scythians (London 2001).

${ }^{101}$ For the extensive literature on this apogee of display in Roman monumental architecture see G. Lugli, Fontes ad topographiam veteris urbis Romae pertinentes XVI (Roma 1965), 43-78; Zanker 1970, op.cit (n.42); M.E. Blake, Roman Construction in Italy from Nerva through the Antonines (Philadelphia 1973), 12-18; C.M. Amici, Foro di Traiano: Basilica Ulpia e Biblioteche (Roma 1982); Scheiper 1982, op.cit (n.15), 134-154; J.C. Anderson, The Historical Topography of the Imperial Fora (Bruxelles 1984), 141-177; M.T. Boatwright, Hadrian and the City of Rome (Princeton 1987), 74-98; S. Stucchi, 'Tantis viribus. L'area della colonna nella concezione generale del Foro di Traiano', Archeologia Classica 41 (1989), 237-292; E.M. Steinby (ed.), Lexicon Topographicum Urbis Romae (Roma 1993-1999), s.v. 'Forum Traiani'; Packer 1997, op.cit (n.42); Packer 2001, op.cit (n.42); Bullettino Comunale 95 (1993), 129-198; 97 (1996), 47-88; M. Wilson Jones, Principles of Roman Architecture (New Haven 2000), 160-174; S. Baiani \& M. Ghilardi (ed.), Crypta Balbi - Fori Imperiali. Archeologia urbana a Roma interventi di restauro nell 'anno del Grande Giubileo (Roma 2000), 72-78; González 2000, op.cit (n.79), 141-154, 227-285; R. Meneghini, 'Il foro di Traiano. Recostruzione architettonica e analisi strutturale', Mitteilungen des deutschen archäologischen Instituts. Römische Abteilung 108 (2001), 245-268.
} 
failed to convince ${ }^{102}$ As a structure the Column allowed visitors to climb the 185 steps of the internal staircase to emerge on the balcony and to view the whole fantastic creation of libraries, basilica and forum piazza. ${ }^{103}$ Modern architectural reconstructions of the basilica which place the roof ridge at a lower height are surely correct to allow for an uninterrupted view southeastwards. ${ }^{104}$ Linked with the enigmatic inscription on the pedestal which refers to the mons removed during work, the engineering achievement was best appreciated by a view across to the cliffs of brick-faced concrete reared against the Quirinal for the Markets of Trajan. ${ }^{105}$

The pedestal reliefs match in content and composition panels depicting congeries armorum which most likely decorated the forum façade of the Basilica Ulpia. ${ }^{106}$ The Dacians on the helical frieze matched the bound Dacian statues which served as 'Caryatids' around the forum colonnades. The evolving composition of the frieze suggests that it was executed before the pedestal decoration. Its 'narrative' of the Dacian Wars was central in explaining how the treasure which paid for the whole complex, ex mamubiis, was acquired through Trajan's Danubian victories. ${ }^{107}$ Perhaps more importantly, it acted as a visual panegyric in praise of Trajan's generalship and of the skills and

\footnotetext{
${ }^{102}$ Anderson 1984, op.cit (n.101), 154-159; A. Claridge, 'Hadrian's Column of Trajan', Journal of Roman Archaeology 6 (1993), 5-21.

${ }^{103}$ This view was presumably enjoyed in 357 when Constantius II came to the city and it lies behind the words of Ammianus Marcellinus 16.10.14 (Packer 1997, op.cit (n.42), 8; Wilson Jones 2000, op.cit (n.101), 162-165; P.J.E. Jones, 'The politics of perpetuation: Trajan's Column and the art of commemoration', American Journal of Archaeology 101 (1997), 60-65). This facility has traditionally been made available to tourists at a price and the revenues produced by both Trajan's Column and the Column of Marcus Aurelius were a strong factor dictating the largely intact survival of both monuments.

${ }^{104}$ For a high ridge reconstruction see Amici 1982, op.cit (n.101), Fig. 72-73, 148; Packer 1997, op.cit (n.42), Fig. 92-93; 96-100; 103-106; 111-113; 121; 126-128. For a lower reconstruction see Packer 1997, op.cit (n.42), 217-244, Frontispiece, Fig. 54; Packer 2001, op.cit (n.42), 198.

${ }^{105}$ CIL VI, 960; Hamberg 1945, op.cit (n.9), 121-24; Settis 1988, op.cit (n.10), 49-56; B.M. Tummarello, 'Foro Traiano. Preesistenze - il problema del mons', Archeologia Classica 41 (1989), 121-124; Packer 1997, op.cit (n.42), 117; Wilson Jones 2000, op.cit (n.101), 164-165.

${ }^{106}$ L. Ungaro \& L. Messa, 'Panelli con rilievi d'armi dal Foro di Traiano: nota preliminare', Archeologia Classica 41 (1989), 215-36; Packer 1997, op.cit (n.42), 225, Cat. 94; Fig. 143; 152; Packer 2001, op.cit (n.42), Fig. 152; 159; Polito 1998, op.cit (n.36), Fig. 130-133. For a suggestion that the base of the Equus Traiani bore similar reliefs see Meneghini 2001, op.cit (n.101), Fig. 5.

107 Dio Cassius 68.14.4-5; Aulus Gellius, Noctes Atticae 13.25.1-2; 28-30. Cf. Column scene CXXXVIII. Zanker 1970, op.cit (n.42), 506, 520-521; Packer 1997, op.cit (n.42), 220-221. See J. Makkay, 'The treasures of Decebalus', Specimina Nova Universitatis Quinqueecclesiensis 10 (1994), 151-215; J. Makkay, 'The treasures of Decebalus', Oxford Journal of Archaeology 14 (1995), 333-343.
} 
discipline displayed by the army under his gifted hand. Symbiosis of emperor and soldiers as comilitones was further reinforced by The Great Trajanic Frieze, which in all likelihood also formed an important part of the complex's political ornamentation. ${ }^{108}$ It specifically advertised the concord between emperor and Praetorian Guard. ${ }^{109}$ Combination of a notice by Aulus Gellius and the disiecta membra of the forum colonnades suggests that the latter were topped by pedestals bearing legionary inscriptions. These pedestals had simulacra of military signa set into their tops, so that each column was surmounted by a bound Dacian, below a legionary title, below legionary standards. The latter were fashioned of gilded bronze and they would naturally have echoed the signa which were presumably picked out in gilding on the shaft of the Column and on the Great Trajanic Frieze. ${ }^{110}$ The fragmentary inscriptions name the legio II Augusta, and possibly legiones XIII Gemina, XV Apollinaris and XX Valeria Victrix, plus the cohors XI./ urb(ana). Legiones $I I$ and $X X$ were in Britain during the Dacian Wars and they may not have supplied vexillationes directly to the Danubian theatre. ${ }^{111}$ If they did not, then it is possible that all the legiones of the empire were included in the inscriptions, and that the Forum was a monument honouring the whole Roman citizen army. It might have seemed invidious to omit units,

\footnotetext{
${ }^{108}$ Plinius, Panegyricus 13.3; Suetonius, Galba 20.1; Tacitus, Agricola 33.2; J.B. Campbell, The Emperor and the Roman Army, 31 BC - AD 235 (Oxford 1984), 32-59. Great Trajanic Frieze: Leander Touati 1987, op.cit (n.11), 88-91; Stucchi 1989, op.cit (n.101), 264-283, Fig. 29; Packer 2001, op.cit (n.42), 198; Fig. 165. In general see J.C.N. Coulston, 'Emperor and army on Trajan's Column: a study in composition and propaganda', in A.M. Liberati (ed.), Traiano Optimus Princeps (Roma-Bucaresti forthcoming).

${ }^{109}$ As argued in detail by the writer elsewhere (Coulston 2000, op.cit (n.78), 98-99).

${ }^{110}$ Coulston 1989, op.cit (n.61), 34; Coulston 2000, op.cit (n.78), 92, n. 114. For standards on Trajanic coins see BMC III, Trajan, No. 456-460, Pl. 17.3-4; No. 679, Pl. 22.12; No. 699, Pl. 23.21; No. 708, Pl. 24.15; No. 946a-947, Pl. 37.2; Belloni 1973, op.cit (n.53), No. 122-123; 395-399; Packer 1997, op.cit (n.42), II, Pl. 70.2. Packer reconstructs the standards around the Forum as life-size models (220; 439; Fig. $61 ; 150 ; 152)$, thus dwarved by the scale of the buildings and other decoration. However, sockets in the tops of pedestal blocks measure $0.090-0.093 \mathrm{~m}$. in diameter (Packer 1997, op.cit (n.42), Fig. Pl. 113.1), approximately twice the size to be expected of a real signum spear-shaft, so there is perhaps room for scaling the parapet standards upwards in size and visibility.

${ }^{11}$ Inscriptions: CIL VI, 2943; 32902.a-c; Zanker 1970, op.cit (n.42), 521; Fig. 36; 38-39; Amici 1982, op.cit (n.104), Fig. 39; Stucchi 1989, op.cit (n.101), 237-253; Packer 1997, op.cit (n.42), 426, Cat. $163 ; 165 ; 179$. For legiones which served in the Dacian Wars see K. Strobel, Untersuchungen zu den Dakerkriegen Traians. Studien zur Geschichte der mittleren und unteren Donauraumes in der hohen Kaiserzeit (Bonn 1984), 85-102. Unfortunately Strobel (ibid., 100-101; 104) assumed that if the titles are inscribed on the Forum then the legiones and cohors in question did participate in the Dacian Wars. There is clearly some danger of circular argument here.
} 
especially those in the Rheinland which had supported Trajan's imperial aspirations during Nerva's principate.

Much of this Trajanic monumental complex can be understood in terms of glorification of emperor and army. However, it is also important that the last Flavian emperor's political and monumental legacy in Rome be fully taken into account. On the face of it this is made difficult by the senatorial damnatio memoriae served on Domitian which swept away his statues, triumphal arches and other propaganda monuments. ${ }^{112}$ Nevertheless, his more substantial buildings, such as the Domus Flavia and the Forum Transitorium, remained intact, if in the latter case 'rubber-stamped' by Nerva. ${ }^{113}$ It is unclear what, if anything of Trajan's Forum was owed to Domitianic planning, but prominent Domitianic buildings will have undoubtedly exerted a strong, competitive influence on both the Trajanic régime and Trajanic architects, especially Apollodorus of Damascus. ${ }^{114}$

Several monumental interrelationships may be explored to illustrate the last assertion. The first refers to the Equus Traiamus, the immense equestrian statue of Trajan which stood in his forum piazza. This may be considered as one of several references back to the Forum of Augustus, in this case to the chariot statue group in the latter's piazza. Both fora also had in common the use of decorative 'Caryatids', and their massive side exedrae, multiply niched for statuary and sheathed in polychrome marbles. ${ }^{115}$ However, the choice of an

\footnotetext{
${ }^{112}$ Suetonius, Domitianus 13.2, 23.1; Dio Cassius 68.1.1; Aurelius Victor, De Caesaribus 11. See G.M. Koeppel, 'Die historischen Reliefs der römischen Kaiserzeit, II, stadtrömische Denkmäler unbekannter Bauzugehörigkeit aus flavischer Zeit', Bonner Jahrbücher 184 (1984), Cat. no. 7-8; R.H. Darwell-Smith, Emperors and Architecture: A Study of Flavian Rome (Bruxelles 1996), 114115; 172-177; 238-241; Steinby 1993-1999, op.cit (n.101), s.v. 'Arcus Domitiani (Fortuna Redux)', 'Arcus Domitiani (Clivus Palatinus)'.

${ }^{113}$ Darwell-Smith 1996, op.cit (n.112), 115-124; Steinby 1993-1999, op.cit (n.101), s.v. 'Domus Augustana, Augustiana'; 'Forum Nervae'.

${ }^{114}$ Dio Cassius 69.4.1. For a discussion of Domitianic and Trajanic architects see W.L. MacDonald, The Architecture of the Roman Empire I. An Introductory Study (New Haven 1965), 127-137. For a potential Domitianic contribution to the Forum Traiani see Aurelius Victor, De Caesaribus 13; Darwell-Smith 1996, op.cit (n.112), 241-243.

115 Steinby 1993-1999, op.cit (n.101), s.v. 'Forum Augustum'; Baiani \& Ghilardi 2000, op.cit (n.101), 71-72. Zanker 1970, op.cit (n.42), 506 makes the Forum Augustum link, but Packer 1997, op.cit (n.42), 261 draws considerably less convincing parallels with the Templum Pacis, based on his belief that the Templum Traiani was a feature of the Trajan's Forum original design. The latter is not a safe assumption (R. Meneghini, 'Templum Divi Traiano', Bullettino Comunale 97 (1996), 47-88; Meneghini 2001, op.cit (n.101), 246-248). For polychrome marble comparisons see M.E. Blake, Roman Construction in Italy from the Prehistoric Period to Augustus (Washington 1947), 56; 58;
} 
equestrian rather than a chariot composition for Trajan's Forum would indubitably have drawn the public mind back to the last great equestrian monument erected in the city, the huge Equus Domitiamus. This statue would have been torn down after Domitian's death, but it was not forgotten due to its central position in the Forum Romanum, its impact on the Forum paving, its entry into literature, and its presumably still-circulating image on commemorative coins. ${ }^{116}$ Thus there was a very vivid image for Trajan to outdo, and in a sense to exorcise, with an even finer equus of his own. That he succeeded is evidenced by his own coin representations and the impact the statue was still having on visitors in the 4th century. ${ }^{117}$ Recent excavation of the Forum Traiani piazza paving has revealed the robbed equus pedestal, 4 by $7 \mathrm{~m}$. in dimensions, and $25 \mathrm{~m}$. further towards the south-east than had been previously assumed. ${ }^{118}$ The standard modern reconstruction plan of the Forum, largely the product of fascist period work, had naturally positioned the Equus Traiani on the crossing point of two axes, the one longitudinal to the complex, north-west to south-east, the other laterally north-east to south-west across the mid point of the two hemicycles. In this position it was logical for the statue to face south-eastwards. Now it is more likely that the statue faced north-westwards towards the basilica. The reason for the asymmetric position was almost certainly to allow intervisibility between the gilded Trajan on his horse and the gilded Trajan on his Column, both statues having the common iconographic feature of carrying a spear, and thus the ridge of the Basilica Ulpia should have been low enough to allow this. ${ }^{119}$

Blake 1973, op.cit (n. 101), 15-17; Packer 1997, op.cit (n.42), 169-172; De Nuccio \& Ungaro 2002, op.cit (n.42), 109-121; 125-127; 138-145; Cat. no. 155-170; 300-329.

${ }^{116}$ Darwell-Smith 1996, op.cit (n.112), 227-233; Fig. 29; Steinby 1993-1999, op.cit (n.101), s.v. 'Equus Domitianus'. See Statius, Silvae 1.1.22-51. There is some confusion about its dimensions and two proposals for its exact original location in the Forum Romanum: either on a robbed pedestal with maximum dimensions of 11.72 by $6.2 \mathrm{~m}$; or on a pedestal, the site of which was paved over in the Severan period with 12.20 by $7.8 \mathrm{~m}$. of flagging. The latter is more centrally placed on the long axis of the Forum, both are towards the south-east end, next to each other. The question of whether the pedestal was left standing and was re-used after Domitian's death is unresolved.

${ }^{117}$ BMC III, Trajan, No. 445, Pl.16.18; No. 969-70, Pl. 38.2; Belloni 1973, op.cit (n.53), No. 117; 418, Ammianus Marcellinus 16.10.15-6. See Zanker 1970, op.cit (n.42), 508-510; Steinby 19931999, op.cit (n.101), II, s.v. 'Forum Traiani', 351, Fig. 175; M. Jordan-Ruwe, Das Säulenmonument. Zur Geschichte der erhölnten Aufstellung antiker Porträtstatuen (Bonn 1995), 82-83; Packer 1997, op.cit (n.42), 8; 95-96; Meneghini 2001, op.cit (n. 101), 253-254; Fig. 5.

${ }^{118}$ Baiani \& Ghilardi 2000, op.cit (n. 101), 73-74; Fig. 62-64; 66; 68; Meneghini 2001, op.cit (n.101), 253; Fig. $2 ; 4(\mathrm{E}) ; 9 ; 18$. Actually on a cross-axis level with the south-east junctions of the hemicycles.

${ }^{119}$ This further reinforces the importance of the Column as a viewing platform. Most examples of the Equus coins are worn at the upper end of the spear, but the lower has a large head. It is likely that this is a double-headed spear, as seen on Trajan's Column (Scenes XXV; XXVII carved in stone, 
Another monumental inter-relationship concerns the dedication ' $e x$ manubiis' recorded by Aulus Gellius on the Forum Traiani. It has recently been demonstrated by Alföldi that the original dedicatory inscriptions on the Amphitheatrum Flavium included the same formula. ${ }^{120}$ As previously suspected, the treasures from Jerusalem and the crushing of the Jewish Revolt were ploughed into the metropolis' most impressive public entertainment facility. The location and public nature of the building erected by Vespasian and Titus had in their time scored propaganda victories over Nero and his Domus Aurea. The Thermae Titi were constructed close by and inaugurated at the same time as the amphitheatre. ${ }^{121}$ Domitian did his best through the arch he raised to his brother Titus to associate himself with the dynasty's Jewish victories. ${ }^{122} \mathrm{He}$ may also have substantially refurbished the amphitheatre,

many more lost bronze inserts), employed as a symbol of power (A. Alföldi, 'Hasta-summa imperii. The spear as embodiment of sovereignty in Rome', American Journal of Archaeology 63 (1959), 127). For the Column statue see $B M C$ III, Pl. 16.19-20; 17.1-2; 19.11-2; 39.4-5; 40.2; 41.6; 42.3; Belloni 1973, op.cit (n.53), No. 118-120;153;332; 420-423. It has further been suggested that Trajan's lavish provision of libraries, both in his baths and in the Forum Traiani complex (the pair flanking the Column) was a deliberate comment on Domitian's expulsion of philosophers from Rome. See Dio Cassius 68.16.3; Amici 1982, op.cit (n.101), 47-69; Settis 1988, op.cit (n.10), 60-75; Packer 1997, op.cit (n.42), 120-130; Packer 2001, op.cit (n.42), 77-82; Meneghini 2001, op.cit (n.101), 248-251; 265-268; L. Casson, Libraries in the Ancient World (New Haven 2001), 84-88; Steinby 1993-1999, op.cit (n.101), V, 68 (baths). Moreover, the one apsidal end of the Basilica Ulpia which is on a surviving fragment of the Severan Forma Urbis Romae carries the inscription 'Libertatis' (Blake 1973, op.cit (n.101), 15; Settis 1988, op.cit (n. 10), 25; Steinby 1993-1999, op.cit (n.101), I, Fig. 170; Packer 1997, op.cit (n.42), 5; 8; Fig. 130) which surely amplified contrasts between the 'tyranny' of Domitian and the humane rule of Trajan (Plinius Minor, Panegyricus 67.8; Epistulae 10.97; Dio Cassius 68.6.3-4; 68.7.1-3; 68.16.1; Aurelius Victor, De Caesaribus 13; Eutropius, Breviarium 8.4). In the discussion of imperial decision-making, always one which will involve a measure of speculative deduction, such interrelationships between monuments must be seen as contributory considerations, not necessarily (or even, ever) as the only factor involved. Recent studies of imperial building policy tread a very fine line between 'coincidental' and 'positivist' approaches to the meanings of urban projects in Rome (Cf. Boatwright 1987, op.cit (n. 101); P. Zanker, The Power of Images in the Age of Augustus (Ann Arbor 1988); D. Favro, The Urban Image of Augustan Rome (Cambridge 1996); Darwell-Smith 1996, op.cit (n.112)).

${ }^{120}$ G. Alföldi, 'Eine Bauinschrift aus dem Colosseum', Zeitschrift für Papyrologie und Epigraphik 109 (1995), 195-226; K.M. Coleman. "The contagion of the throng": absorbing violence in the Roman world', European Review 5 (1997), 402-405; Fig. 1.

${ }^{121}$ Steinby 1993-1999, op.cit (n.101), s.v. 'Thermae Titi/Titianae'. Also combating Nero's reputation as a provider of baths (Martialis 7.34).

${ }^{122}$ Darwell-Smith 1996, op.cit (n.112), 166-72; Steinby 1993-1999, op.cit (n.101), s.v. 'Arcus Titi (Via Sacra)'. 
although quite what he did to it still divides scholarly opinion. ${ }^{123}$ Ancillary facilities were rebuilt or provided anew in the area around the amphitheatre, particularly the various ludi. ${ }^{124}$ Domitian would have held his triumphal games in the amphitheatre, and Dacians, Germans and Sarmatians would have been displayed there. ${ }^{125}$

Trajan was quite able to upstage this Flavian beneficence. His triumphal games held in the amphitheatre broke all records for numbers of gladiators and animals involved. ${ }^{126}$ Presumably the number and range of barbarians on display was also unprecedented. The Thermae Traianae were constructed on the Oppian Hill on a gigantic scale and richly appointed, overlying the Domus Aurea wing, but also dominating the locale and completely dwarfing the rather cramped Thermae Titi directly below. ${ }^{127} \mathrm{He}$ could not build another amphitheatre because not even Rome had room for two 'colossea', but he did massively enlarge the seating capacity of the Circus Maximus, an even grander venue. ${ }^{128}$ Its euripus was decorated thereafter with military standards in the manner of the Forum Traiani, a clear visual link between Trajanic projects. ${ }^{129}$ The circus had been associated with the Flavians by the Arch of Vespasian and Titus and other Domitianic work. Furthermore, Trajan could still upstage the amphitheatre's manner of Flavian dedication. The manubiae which paid for the Forum Traiani were the result of a successful war which led to traditional triumphs, booty, annexation of territory and patronage for the city of Rome. The Jewish War had been a savage, internal policing operation which had started with ignominious

${ }^{123}$ Darwell-Smith 1996, op.cit (n.112), 215-216; Steinby 1993-1999, op.cit (n.101), I, s.v. 'Amphitheatrum', 31; K.M. Coleman, 'Launching into history: aquatic displays in the early empire', Journal of Roman Studies 83 (1993), 58-60.

${ }^{124}$ Darwell-Smith 1996, op.cit (n.112), 218-221; Steinby 1993-1999, op.cit (n.101), s.v. 'Ludus Dacicus', 'Ludus Gallicus', 'Ludus Magnus', 'Ludus Matutinus'. It is unsure when the Ludus Dacicus acquired its name, whether in association with the wars of Domitian or those of Trajan.

${ }^{125}$ Dio Cassius 67.8; Suetonius, Domitianus 6.1; Eutropius, Breviarium 7.23. Martialis, Liber de spectaculis 3 mentions Sugambri and Sarmatae as 'spectators' of the Flavian amphitheatre, perhaps meant involuntarily?

${ }^{126}$ Plinius Minor, Epistulae 8.4.2; Dio Cassius 68.10.2; 68.15.1.

${ }^{127}$ Steinby 1993-1999, op.cit (n.101), s.v. 'Thermae Traiani'.

${ }^{128}$ Plinius, Panegyricus 51.3-5; Pausanios 5.12.6; Dio Cassius 68.7.2; CIL 6.955; J.H. Humphrey, Roman Circuses. Arenas for Chariot Racing (London 1986), 102-106; 281; Fig. 119 (Fig. 120 shows a trophy on the euripus, further strengthening the links between military and sporting victory). Cf. BMC III, Trajan, No. 853-56, P1. 32.2-4: Belloni 1973, op.cit (n.53), No.360 for Trajanic coins depicting the Circus Maximus.

${ }^{129}$ C.Landes (ed.), Le cirque et les courses de chars Rome - Byzance (Lattes 1990), Pl. II. 
Roman defeat and ended in the destruction of one of the empire's great cities with its magnificent temple. ${ }^{130}$ Much was made of it by the Flavians because it was a war against non-Romans, waged successfully during and after Roman civil war. In complete contrast, Decebalus was a barbarian, and, above all, a foreign king. He also had the distinction of being the only named barbarian leader represented in Roman art. ${ }^{131}$

The injection of veristic detail into Trajanic monumental art may also be considered in the light of Flavian precedents, but it was not a reflection of any intrinsic novelty value of the Dacians. On the contrary, they were not new to Roman warfare or public perceptions. Roman armies had campaigned in the Danubian theatre and Dacians had been raiding across the Danube since the time of Augustus. Sarmatian groups drove opportunistically into Moesia during the Roman civil war of AD 68-69. Most significantly, Domitian had fought a recent series of Danubian wars. ${ }^{132}$ There were several ways in which such conflict with Dacians and other Danubian barbarians could have been presented to the public audience in Rome. The most immediate was the display of barbarian prisoners walking dejectedly in triumphal processions, wearing their characteristic clothing and hairstyles. Trophies with prisoners bound to them were arranged on fercula, and captured military equipment were also borne along, perhaps piled in such a way as to clash bellicosely as they moved. ${ }^{133}$ This was often supplemented by the carriage of painted panels in the procession depicting significant stages of the war concerned, such as landscapes, sieges, battles and enemy submissions. This form of art had a very long pedigree and was specifically mentioned by Josephos in the context of the Jewish triumph of Vespasian and Titus. ${ }^{134}$ Most scholars agree that this

\footnotetext{
${ }^{130}$ Supposedly unintended, as witnessed by Titus' vain attempts to extinguish the fire (Josephos, Bellum Iudaicum 6.249-266).

${ }^{131}$ Settis 1988, op.cit (n.10), 226-228; Fig. 62; Ferris 2000, op.cit (n.34), 80-81.

${ }^{132}$ Dio Cassius 67.6; 67.7.2-5; 67.10.1-3; Juvenal, Satirae 4.111-112; Eutropius, Breviarium 7.23; C. Patsch, Der Kampf um den Donauraum unter Domitian und Trajan (Wien 1937), 3-47; Wilkes 1983, op.cit (n.98), 268-270; B.W. Jones, The Emperor Domitian (London 1992), 135-139; 141-143; 150-155.

${ }^{133}$ E. Künzl, Der römische Triumph. Siegesfeiern im antiken Rom (München 1988), 74-78; 110-113; Fig. 43-48. The detail of clashing arms comes from Plutarch's description of the triumph of Aemilius Paullus in Plutarch, Aemilius Paulus 32.5-7. Cf. Ovidius, Ex Ponto 2.1.40; Plinius Minor, Panegyricus $17.1 ; 17.3$ ). It is not at all unlikely that the author was embroidering the passage with familiar details from triumphs held in his own time, the 2 nd century $\mathrm{AD}$. Indeed, the description is not inappropriate for the material depicted on the pedestal reliefs of Trajan's Column.

134 Josephos, Bellum Iudaicum 7.139-147. See also Livius 41.28.8-10; Appianos, 2.101; 12.117; Ovidius, Ex Ponto 2.1.37-39; Tristia 4.2.37-38; Plinius Maior, Naturalis Historia 35.135; Tacitus, Annales 2.41.
} 
painted form of display lay behind and greatly influenced the more permanent scenes executed in stone sculpture on triumphal monuments, and that it was also important for the evolution of the scene genres (sacrifice, march, battle, negotiation, siege, submission etc.) which make up the helical frieze of Trajan's Column. ${ }^{135}$ Such displays would have marked Domitian's Danubian triumphs and would have combined with, and been extended into, amphitheatrical games. However, it seems that the barbarian congeries armorum, and the barbarians themselves, had a negligible effect on Domitianic sculpture.

If the hostile élite literary tradition is to be believed, Domitian's wars were partly disastrous, involving loss of significant forces and leading personalities (e.g. Cornelius Fuscus), and they ended in a humiliating peace treaty which left the barbarian protagonist, Saddam-like, in place as a future threat. His triumphs were mocked as shams. ${ }^{136}$ Trajan effectively attended to unfinished business and carried Daco-Roman relations to a final conclusion. Roman prisoners and military equipment were recaptured; great rivers were bridged; victories were won to expunge Domitianic reverses; losses were avenged; fortresses were stormed; a new province was acquired with its precious metals (Trajan's Column Scene CXXXVIII); and the barbarian king was hunted to extinction (CXLV, CXLVII) ${ }^{137}$ If the chief protagonist was not himself paraded through Rome in chains, his head was brought to the city and thrown down the Scalae Gemoniae. ${ }^{138}$

Thus, as in so many other things, the Trajanic régime was concerned to advertise its differences from Domitianic policies ${ }^{139}$ and to separate itself

\footnotetext{
${ }^{135}$ Lehmann-Hartleben 1926, op.cit (n.10), 2; 101-102; Hamberg 1945, op.cit (n.9), 125-129; R.C. Beacham, The Roman Theatre and its Audience (London 1991), 181; Settis 1988, op.cit (n.10), 94100; Künzl 1988, op.cit (n.133), 110;114-118; 162. For the most detailed discussion of genre scenes see Lehmann-Hartleben 1926, op.cit (n.10), 11-108.

${ }^{136}$ Plinius Minor, Panegyricus 16.3; Dio Cassius 67.8-9 stated that the public felt that his honouring the fallen in Dacia made his triumph a funeral. Tacitus, Agricola 39 accused Domitian of purchasing slaves and, a significant detail for the present enquiry, modelling their clothes and hair to deceive viewers of his German triumph. On the ambivalence of triumphal displays see Plass 1995, op.cit (n.69), 148-154.

${ }^{137}$ For the realities see Patsch 1937, op.cit (n.132), 62-86; 93-134; Wilkes 1983, op.cit (n.98), 270274; Strobel 1984, op.cit (n.111).

${ }^{138}$ Steinby 1993-1999, op.cit (n.101), s.v. 'Scalae Gemoniae'. Was this act also intended to reinforce Trajan's just rule during which Roman corpses and severed heads were not thrown down the steps? Cf. n. 77 , above.

${ }^{139}$ All the more crucial because Trajan's policies were in reality almost indistinguishable from those of his predecessor! See K.A. Waters, 'Traianus Domitiani continuator', American Journal of Philology 90 (1969), 385-405.
} 
by emphasising Domitianic failures. Masses of prisoners for the triumphal processions and the amphitheatrical games underlined the justice of Trajan's triumphal claims after each war. Indeed, the despairing Decebalus' suicide was most likely presented in the arena as a form of historical tableau, to judge from terra sigillata motifs depicting the named king stabbing himself whilst flanked by venatio animals. ${ }^{140}$ One design also figures a Parthian flanked by lions, thus combining and epitomising the Dacian and Parthian victory celebrations. Description of the Dacian Wars in Trajan's own commentarii ${ }^{141}$

${ }^{140}$ Settis 1988, op.cit (n.10), Fig. 62-63. Perhaps an actor was carried through the triumphal procession on a ferculum, periodically miming the cutting of his own throat (Cf. Plinius Minor, Epistulae 8.4.2; Dio Cassius 68.14.3). A parallel might be drawn with the popular amphitheatrical restaging over decades of the execution of the criminal Laureolus (Suetonius, Gaius 57.4; Martialis, Liber de spectaculis 7; Juvenalis, Satirae 8.187). Live, captured commanders of cities were combined with painted scenes in Titus' triumph (Josephos, Bellum Iudaicum 7.147. Cf. Plinius Minor, Panegyricus 17.2). A Constantinian relief from Cherchel (Algeria) appears to depict a triumphal ferculum bearing the model of a bridge (the Pons Mulvius? Künzl 1988, op.cit (n.133), 7879; Fig. 47). This raises the possiblity that Trajan's great Danube bridge, an engineering wonder of its age, was similarly represented to the viewing public (Cf. Trajan's Column Scene XCIX; Coulston 1990, op.cit (n.60), 49; Coulston 2001, op.cit (n.60), 124). There is also the likelihood that tableaux were staged in Rome's theatres, and these might have been another mechanism for familiarising the public with the highlights of the Dacian Wars. From the time of Pompeius Magnus theatres were linked with triumphs and triumphal processions, and were used for venationes (Beacham 1991, op.cit (n.135), 162-163; 180). Parallels might be drawn with the Victorian theatre which presented wars as a series of vignettes or generic scenes very similar to those on Trajan's Column. For example, for the 1885 Relief of Khartoum "spectacular scenes included the departure of troops from Portsmouth, a street bazaar in Cairo, a bivouac in the desert, a battle scene, even cataracts, rocks and boats on the Nile. The final scene took place in Khartoum itself" (J.M. MacKenzie, Propaganda and Empire. The Manipulation of Public Opinion, 1880-1960 (Manchester 1984), 51). The theatre (and the many other available media) also provided the public with the visually identifiable 'barbarian' types: Zulus, Fuzzy-Wuzzies, Boers, Afghans, Russians, Chinese and Japanese (ibid., 49-50). See also J.S. Bratton, R.A. Cave, B. Gregory, H.J. Holder \& M. Pickering, Acts of Supremacy. The British Empire and the Stage, 1790-1930 (Manchester 1991). See also Appianos 12.117 for native costume in the theatre, and Hall 1989, op.cit (n.26), 84-86 for the use of ethnic dress as stage costume in the Athenian theatre. Depiction of a range of non-Roman troops on Trajan's Column as part of Trajan's army can be parallelled on Pharaonic and Assyrian reliefs. They denoted geographical power and discipline under the pharaoh/king/emperor's strong hand. The archers and slingers were artificialy fabricated figure types, created especially for the Column project (Coulston 1989, op.cit (n.61), 34), but the Moors were likely based on exotic troops in Trajan's triumphs (Cf. Dio Cassius 68.32.4) and/or prisoners from recent North African wars (Tacitus, Historiae 4.50; Plinius Maior, Naturalis Historia 5.38; Dio Cassius 67.4.6). A range of native or colonial 'Soldiers of the Queen' was similarly exhibited in the Victorian theatre and in the great military reviews of the 19th-20th century in Britain (MacKenzie 1984, 72).

${ }^{141}$ Priscianus, Institutiones Grammaticae 6.13; R. Brilliant, Visual Narratives. Storytelling in Etruscan and Roman Art (Ithaca 1984), 101-102; Lepper \& Frere 1988, op.cit (n.10), 26; 226-229; Settis 1988, op.cit (n. 10), 73-75. 
and their depiction in unprecedented detail on the helical frieze of Trajan's Column presented the events and achievements to the public in more lasting forms. The new verism in the depiction of barbarians, particularly with its emphasis of exotic dress and weaponry, served to fix in public consciousness the reality of Trajanic victories. The collection of large quantities of material after a battle was really only practical for a victor holding the field. Equipment was thus depicted in huge quantities on the Column pedestal and elsewhere in the Forum complex, and reproduced in more abbreviated form on numerous coin issues. ${ }^{142}$ Thus, the barbarian enemy was not just physically brought to Rome, he was 'reinvented' as new, vivid and real. Undoubted Domitianic successes were to be forgotten, just as the hated emperor's arches and statues had been excised from the city-scape. Trajan's victories were tangible and unequivocally glorious. The barbarian was exposed in the amphitheatre arena in person, and in the Forum Traiani in simulacrum. The latter context allowed him to bear witness forevermore to the achievements of the optimus princeps.

The depiction of barbarians in Trajanic art was founded on traditions stretching back to the Bronze Age. It owed much to Graeco-Roman understanding and perception of the barbarian 'other', passed through Graeco-Persian relations in the Archaic period, to feed forward still into the modern era of post-colonial perspectives. ${ }^{143}$ The very depiction of barbarians was an act of power over the subject, reducing them to exotic bystanders of Roman triumph. Stereotypes of dress, hair, weaponry, other equipment, and behaviour had built up and solidified around the concept of 'Gauls' and 'Germans' by the late 1 st century BC. The Dacians were comparatively recent on the Roman metropolitan scene; they were more heavily dressed than other types of barbarians, and exhibited both old features, such a carnyces, and exotically new items, such as falces and 'dracones'. Otherwise they were presented in a almost indulgent manner at a time when Rome was at the height of her power ${ }^{144}$ (in complete contrast to how later barbarians

${ }^{142}$ BMC III, Pl. 15.6-9; 15.14-15; 20.6-7; 24.6; 24.8; 24.10; 28.6-8; 30.2; 34.1; 34.11-12; 36.3; 37.36: Belloni 1973, op.cit (n.53), No. 45; 53; 99-101; 104-107; 164-165; 186; 270-279; 313-315; 346$350 ; 400-401$.

${ }^{143}$ Notably examined by E. Said, Orientalism (London 1978).

144 Paternalism and clemency are features of Trajan's treatment of the Dacians, especially their women, and such benevolence may be seen as a mark of imperial confidence. Cf. Said 1993, op.cit (n.2), xviii-ix: "(No American has been immune from) the rhetoric of the 'New World Order' promulgated by the American government since the end of the Cold War - with its redolent selfcongratulation, its unconcealed triumphalism, its grave proclamations of responsibility.... since the 
were treated on the Marcus Column ${ }^{145}$ ). They were negotiated with, beaten down in war, and forced to conform with the Roman world order, but also shown some respect for their dignitas, and some clementia for those who submitted in good faith. Their gold contributed to the adornment of Rome, whilst a river of their blood washed away the parvenu illegitimacy of the Trajanic régime.

St Andrews and Dublin, December 2002

rhetoric of power all too easily produces an illusion of benevolence when deployed in the imperial setting. Yet it is a rhetoric whose damning characteristic is that it has been used before not just once (by Spain and Portugal) but with deafening repetitive frequency in the modern period, by the British, the French, the Belgians, the Japanese, the Russians, and now by Americans".

${ }^{145}$ The differences between the two columns can readily be explained. Trajan's Dacian Wars were offensive campaigns launched into barbaricum against an identified enemy leader, resulting in clearcut victory, submissions of long-known and newly contacted peoples, territorial annexations and treasure to pay for the Forum complex. Marcus' Danubian Wars were expensive, confused, bloody and ended in no annexations. Crucially they involved barbarian invasion of Italy - the first such incursion in 270 years. Thus Trajan's campaigns were a triumphal progress whilst Marcus' wars were a terrible shock to Roman perceptions of security. On the first Column the barbarians are slaughtered but treated honourably; on the second they are exterminated. See H.W. Böhme, 'Archäologische Zeugnisse zur Geschichte der Markomannenkriege (166-180 n. Chr.)', Jahrbuch des Römisch-Germanisches Zentralmuseum 22 (1975), 153-217; A. Birley, Marcus Aurelius (London 1987), 159-183; 208-209; H. Friesiger, J. Tejral \& A. Stuppner (eds.), Markomannenkriege. Ursachen und Wirkungen (Brno 1994); Ferris 2000, op.cit (n.34), 86-118. 